\title{
Platforms for Plant-Based Protein Production
}

\author{
Jianfeng Xu, Melissa Towler, and Pamela J. Weathers
}

\section{Contents}

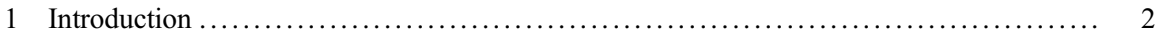

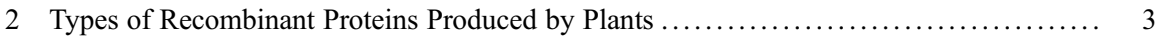

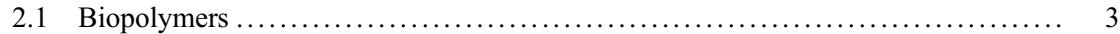

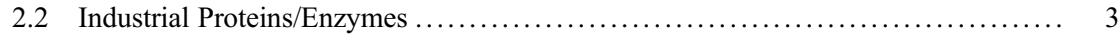

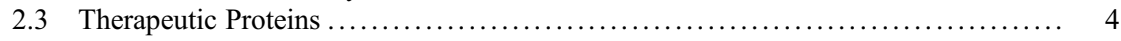

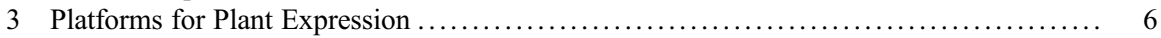

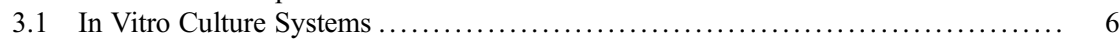

3.2 Aquatic Plants .................................................... 14

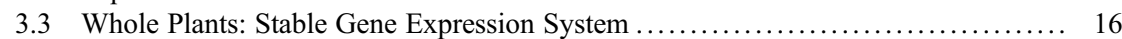

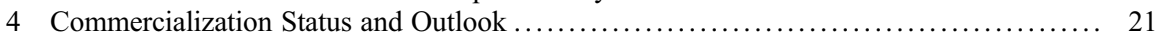

4.1 Plant-Produced Industrial Proteins/Enzymes ............................ 24

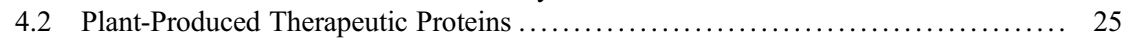

4.3 Plant-Produced Biopolymers ........................................ 27

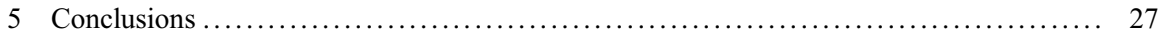

References $\ldots \ldots \ldots \ldots \ldots \ldots \ldots \ldots \ldots \ldots \ldots \ldots \ldots \ldots \ldots \ldots \ldots \ldots \ldots \ldots \ldots \ldots \ldots \ldots \ldots \ldots \ldots \ldots \ldots \ldots \ldots, 28$

\section{Abstract}

Plant molecular farming depends on a diversity of plant systems for production of useful recombinant proteins. These proteins include protein biopolymers, industrial proteins and enzymes, and therapeutic proteins. Plant production systems include microalgae, cells, hairy roots, moss, and whole plants with both stable and transient expression. Production processes involve a narrowing diversity of bioreactors for cell, hairy root, microalgae, and moss cultivation. For whole plants, both field and automated greenhouse cultivation methods are used with

J. Xu

Arkansas Biosciences Institute, Arkansas State University, Jonesboro, AR, USA

M. Towler • P.J. Weathers $(\bowtie)$

Biology \& Biotechnology Department, Worcester Polytechnic Institute, Worcester, MA, USA

e-mail: weathers@wpi.edu 
products expressed and produced either in leaves or seeds. Many successful expression systems now exist for a variety of different products with a list of increasingly successful commercialized products. This chapter provides an overview and examples of the current state of plant-based production systems for different types of recombinant proteins.

\section{Keywords}

Molecular farming • Recombinant protein expression - Therapeutic proteins • Transient expression $\bullet$ Bioreactor

\section{Introduction}

Photosynthesis or use of simple growth media provides clear advantages for using plants to produce biomass and protein products at low cost [1-3]. The majority of posttranslational modifications important for many complex eukaryotic proteins can be performed by plants, whose species diversity offers variety in production platforms from in vitro cultures through field crops, all within established regulatory guidelines. Of particular benefit is that plants cannot harbor human and animal pathogens that can plague in vitro mammalian production systems, so plants provide major advantages in product safety, especially for therapeutics [4, 5]. Such safety advantages also reduce purification costs and minimize production shutdowns and facility decontamination, thereby affecting patient/customer demand. Costs to purify plant-produced proteins are comparable to microbial or mammalian cell culture systems, but plants offer key advantages with lower up-front capital costs and potential economies of scale. Direct use of cultivated plant cells, whole or minimally processed plants, or plant parts (e.g., seeds, dried leaves) is in development for industrial/bioenergy applications as well as for therapeutics and vaccines, thereby further reducing costs of recombinant proteins [6-12]. Boosting protein yields is always a challenge for economic feasibility $[2,5]$ as are regulatory considerations, some of which are unique to plant bioproduction systems [1, 13].

Plant expression platform diversity includes: whole plants, suspension cells, hairy roots, moss, duckweed, and microalgae. There are strengths and weaknesses to each platform with selection often determined by type of recombinant protein, market, scale, cost, and up and downstream processing constraints of the specific protein product. Within each platform is also a diversity of plant species that can host the protein product. Platform diversity provides flexibility in expressing novel recombinant proteins, enables customizing and meeting scale-up needs, and provides opportunity for oral-based delivery of proteins. However, such diversity also may complicate regulatory compliance, which prefers more uniformity. Here we summarize prospects and challenges associated with each type of plant production platform and production strategy, and where appropriate, comments are provided on important regulatory issues and progress toward commercialization. 


\section{Types of Recombinant Proteins Produced by Plants}

Plant-made recombinant proteins are generally categorized into three classes, usually based on function and/or application: biopolymers, industrial proteins/enzymes, and therapeutic proteins. Examples of each of these groups are briefly described in the following sections.

\subsection{Biopolymers}

Although plants are expert at bulk production of biopolymers such as cellulose and starch, here the focus is on recombinant protein-based biopolymers such as elastinlike polypeptides (ELPs), spider silk proteins, collagens, and plant gums (see review [14]). The ELPs that are repetitive pentapeptide sequences (VGVPG) mainly serve as thermally responsive tags for non-chromatographic purification of recombinant proteins [15]. ELP tags significantly enhanced production yield of different recombinant proteins in plant leaves $[16,17]$. Collagen and spider silk proteins (spidroins) serve as two interesting examples.

Collagen is a critical extracellular matrix (ECM) material and connective tissue in animals; commercial supplies are typically extracted from cadavers or animal sources, so a safer source is desirable [18]. Large-scale production of recombinant human collagen type I (rhCOL1) in tobacco is now providing low-cost functional biocompatible ECM that is safer than cadaver or animal sources for use in creating scaffolds for tissue engineering, skin, and wound healing [19, 20].

Spidroins are modular fibrous proteins with highly repetitive amino acid sequences consisting mainly of glycine and alanine [21, 22]. Silk fibers spun from these spidroins have exceptional flexibility, elasticity, and toughness - three times as strong as Kevlar and five times as strong as steel [23]. Plant production is more efficient and cheaper than microbial recombinant spidroins. Transgenic tobacco and potato plants expressing Nephila clavipes synthetic genes of dragline spidroin have yielded recombinant silk proteins up to $2 \%$ of total soluble protein (TSP) in the ER [22]. Arabidopsis dragline spidroins reached 18\% of TSP in seeds [24]. Challenges remain in developing manufacturing technology for spinning fibers into more useful products [25].

\subsection{Industrial Proteins/Enzymes}

Industrial proteins are defined as commodity chemicals used in very large quantities and thus must be produced at very low cost [26]. Transgenic field plants are particularly attractive for producing industrial proteins/enzymes because agricultural production is low cost, protein products stored in specific organs such as seeds are stable, scale-up is easy and relatively fast, and crude plant materials can often be used directly in industrial processes $[6,7]$. Industrial proteins of most interest are hydrolases, including glycosidases (e.g., cellulase, $\alpha$-amylase, and $\beta$-glucuronidase 
(GUS)) and proteases (e.g., trypsin). The first company to develop and commercialize plant-based recombinant proteins/enzymes, with GUS and avidin being their first two commercialized products, was ProdiGene Inc. (formerly in College Station, TX), which is unfortunately now out of business [3, 7, 27].

Corn seed is considered an ideal platform for industrial protein/enzyme production because this plant has the largest annual grain yield and relatively high seed protein content $(10 \%)$, offering the highest potential recombinant protein yield per hectare [28]. Regulation is a major hindrance to using plant-made industrial proteins/ enzymes because a large acreage of transgenic plants is needed. Use of a food/feed crop for nonfood/feed products may also meet political resistance when, as projected, global food supplies become limited, therefore requiring new solutions.

\subsection{Therapeutic Proteins}

Biopharmaceutical sales are projected to reach \$US 278.2 billion by 2020 . Although transgenic plants can produce fully functional mammalian proteins, including blood proteins, vaccine antigens, monoclonal antibodies (mAbs), cytokines, therapeutic enzymes, growth factors, and growth hormones [5, 29-31], bioactivity requires proper folding, disulfide bond formation, subunit assembly, and often proteolytic cleavage and/or glycosylation. Plants can produce lower-cost, safer therapeutic proteins than mammalian cells [30] and may be the only production system available, e. g., for production of secretory antibodies (sIgAs) [2]. These recombinant therapeutic proteins are produced using many different plant-based platforms including cells and field crops; the most common production species is tobacco. Protein yields have reached well over $25 \%$ of TSP [32] $247 \mathrm{mg} \mathrm{L}^{-1}$ [33].

Plants successfully perform N-linked glycosylation of proteins at the signature recognition motif $(\mathrm{N}-\mathrm{X}-\mathrm{S} / \mathrm{T})$ with subsequent processing in the Golgi complex. As a result, plant glycans differ from those found in mammalian cells. Using plants as hosts to produce therapeutic glycoproteins results in addition of plant-specific xylose and $\alpha-1,3$-fucose sugars; these may alter bioactivity or immunogenicity in humans $[34,35]$. The $\beta$-1,4-galactose or sialic acid residues synthesized in mammals are not naturally produced in plants [31,35-37], so RNAi strategies have been used to engineer more humanlike glycosylation machinery in plants by knocking down fucosyl- and xylosyltransferases in plant transgenic lines expressing a human or chimeric $\beta$-1,4-galactosyltransferase [38-40]. Furthermore, tobacco plants infiltrated with Agrobacterium tumefaciens produced human antibodies with humanlike $\mathrm{N}$-glycans when co-expressed with a chimeric human $\beta$-1,4-galactosyltransferase [41]. The first human-injected therapeutic with greatest clinical experience (Protalix's taliglucerase alfa; discussed further below) did not trigger significant patient antibody production [42-44]. Indeed, plant-specific posttranslational modifications (PTMs) may offer opportunities for producing novel recombinant proteins with enhanced function and efficacy as well as biosimilars [45]. "Second generation" plant-made pharmaceutical proteins are emerging, wherein therapeutic targets are specifically engineered to enhance or produce new therapeutic proteins that integrate 


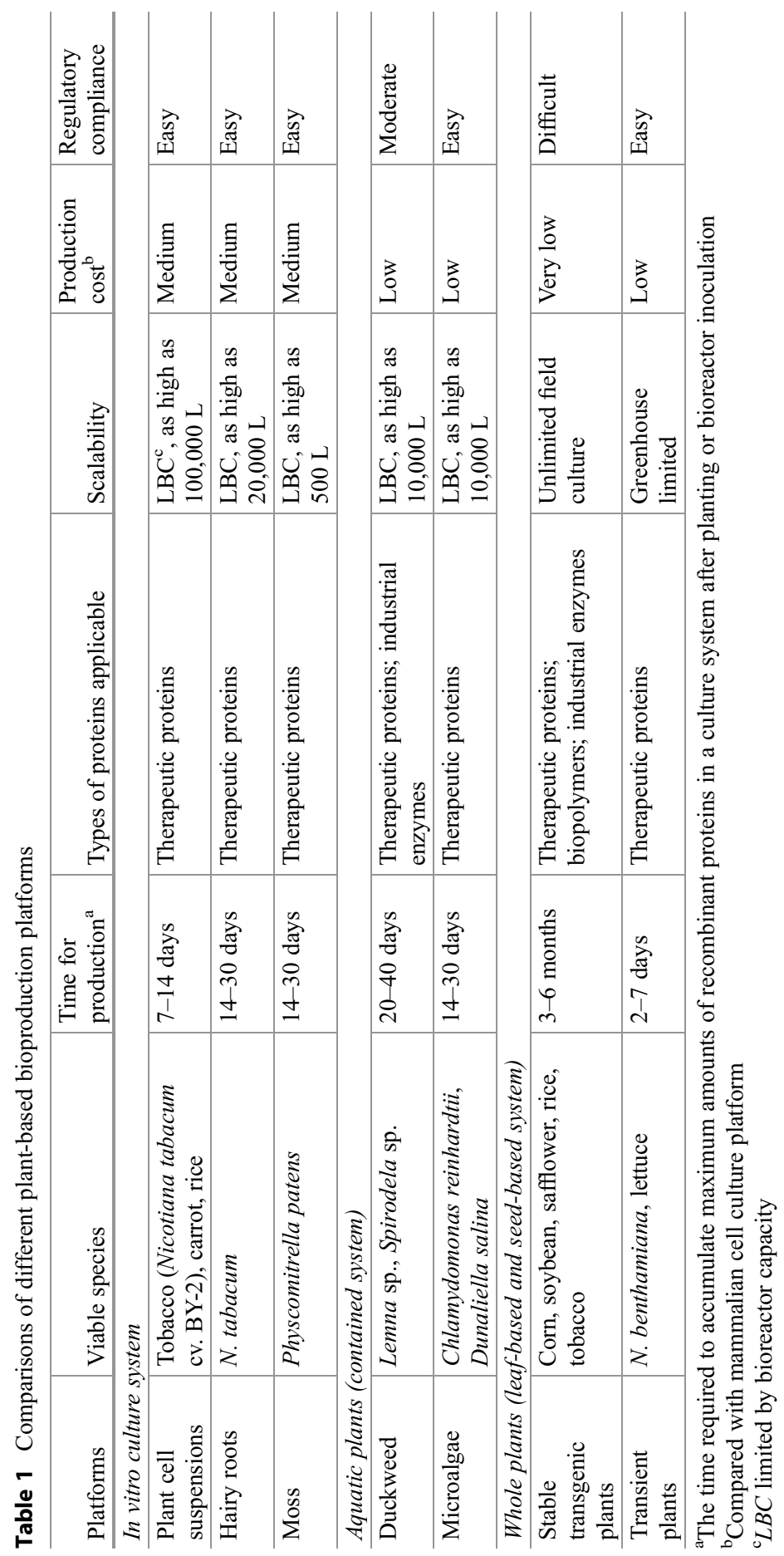


novel motifs or fusion to facilitate protein assembly, delivery, trafficking, protein stability, serum longevity, or protein solubility in either the production host or the target organism (e.g., [31, 46-49]).

\section{Platforms for Plant Expression}

Advances in plant molecular engineering technologies have expanded the diversity of plant bioproduction platforms, ranging from cell and tissue cultures under sterile and contained conditions to whole plants grown under glass or in the field [2]. These bioproduction platforms can be classified as: (1) in vitro culture systems including cell suspensions, hairy roots, and moss protonema, (2) aquatic plants including duckweed and microalgae, and (3) whole plants using both stable and transient expression. The stable expression of whole plants also includes leaf- and seed-based systems. Characteristics of each platform and their strengths and weaknesses are described here. A comparison of the cost, applicability, time needed for production, scalability, and regulatory compliance of different platforms is shown in Table 1.

\subsection{In Vitro Culture Systems}

Plant biomass (e.g., suspension cells, hairy roots, and moss) can be propagated in confined bioreactors under sterile conditions for large-scale production of recombinant proteins. In vitro culture allows for precise control over growth and protein production, batch-to-batch product consistency, and a production process aligned with current good manufacturing practices (cGMP) [5]. Due to its relatively high cost of production, in vitro cultures are often used to produce high-value protein therapeutics. Compared with the other plant-based platforms, in vitro cultures are more acceptable to the pharmaceutical industry with fewer regulatory and environmental concerns [50]. Like other bioreactor-based culture systems, scalability of in vitro cultures is limited by bioreactor capacity. However, because recombinant proteins can be secreted into culture media, downstream processing of recovery and purification of the proteins becomes less expensive than from whole plants [51]. Indeed, the first licensed pharmaceutical protein derived from plants for human use - taliglucerase alfa (Elelyso ${ }^{\mathrm{TM}}$ ) - was produced in carrot suspension cells. Examples of representative recombinant proteins produced using in vitro cultures are shown in Table 2.

\subsubsection{Plant Cell Suspensions}

Undifferentiated clusters of plant callus can be dispersed and propagated in a liquid medium to generate stable cell suspension cultures that retain the same production capacity as whole plants. The production of recombinant proteins in plant cell culture was first demonstrated in 1990 with the expression of a human serum albumin in tobacco cells [78]. Since then, a wide array of biologically active proteins, including antibodies, vaccine antigens, growth hormones and factors, 

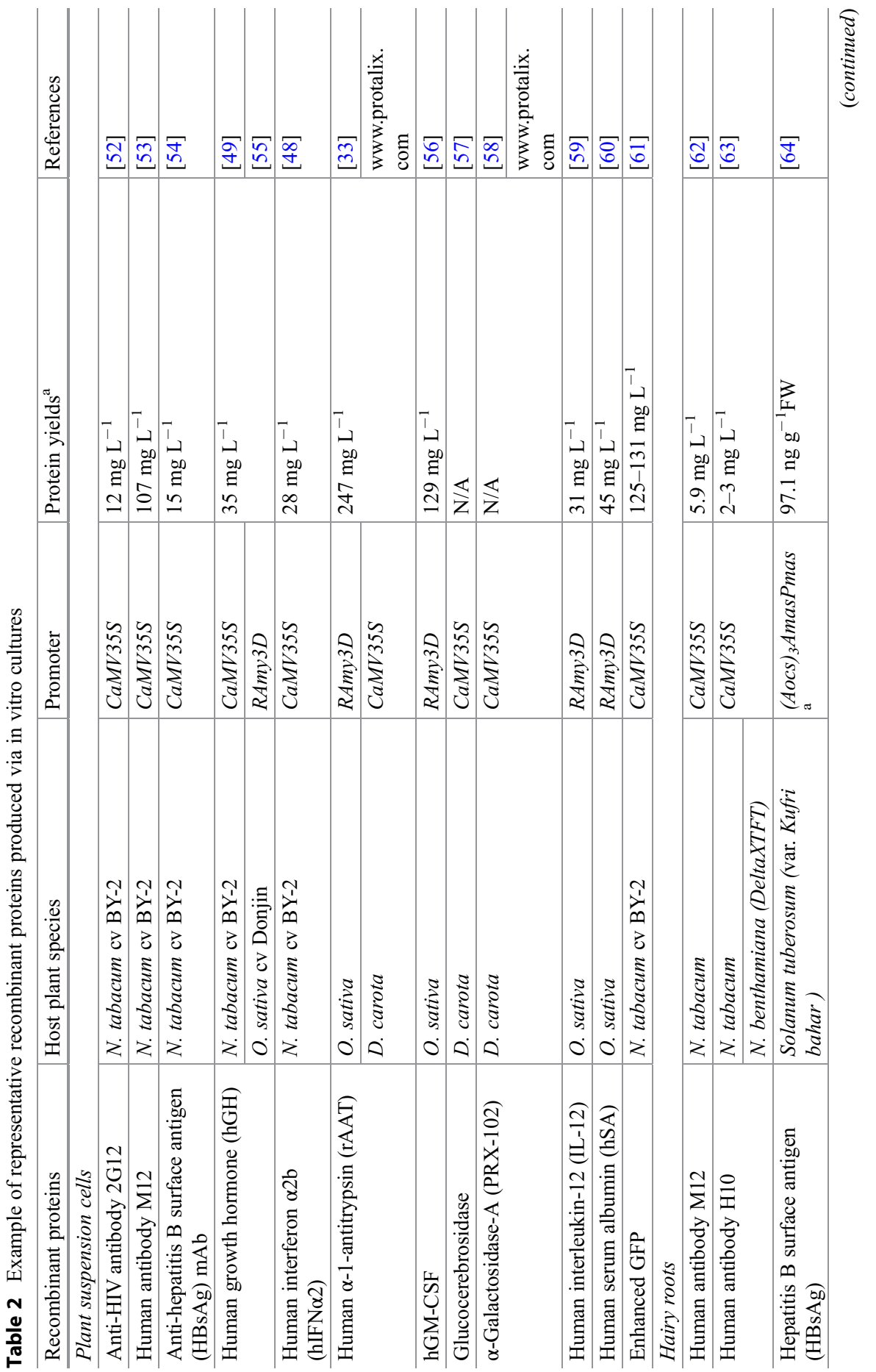


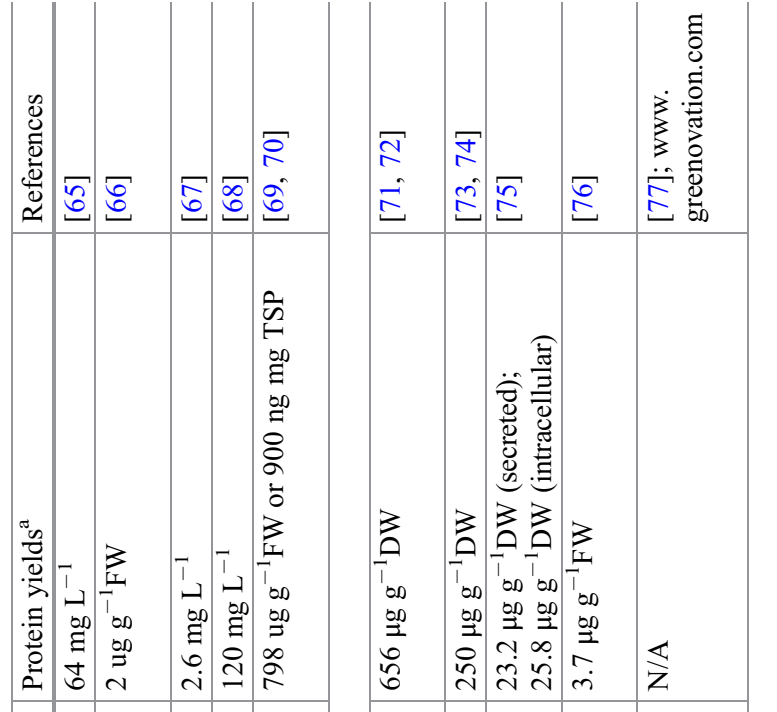

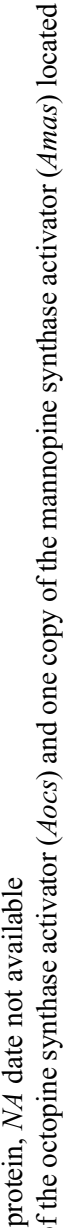

竞

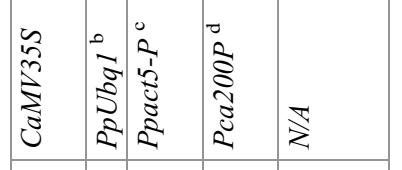

.

(1)
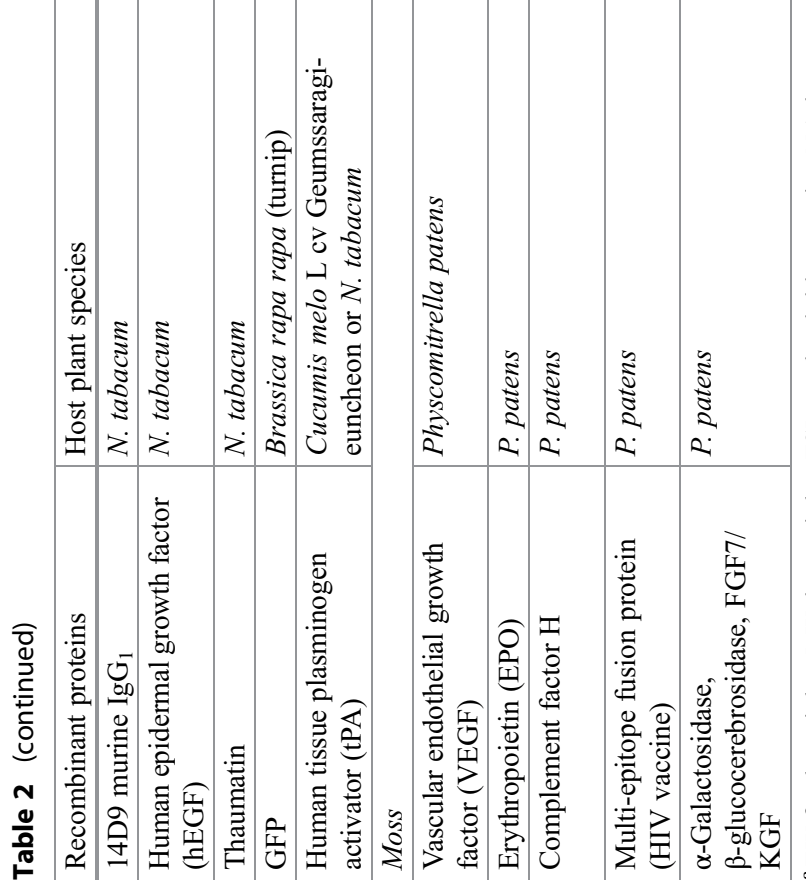

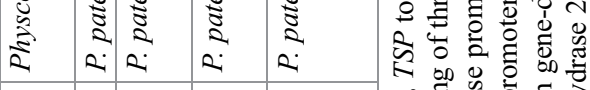

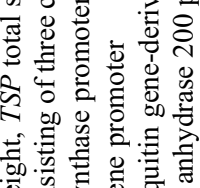

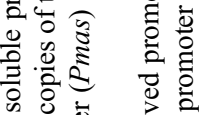

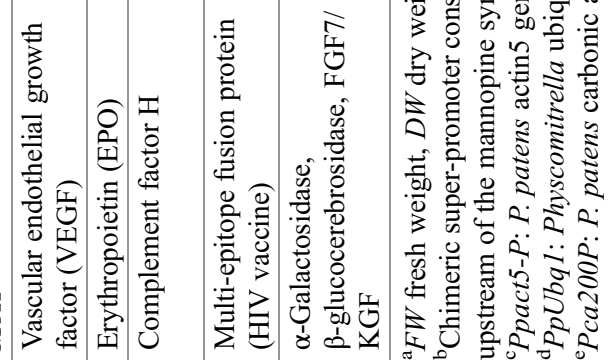


cytokines, and therapeutic enzymes, have been successfully produced in plant cell culture. See recent reviews $[5,50,79]$.

Plant suspension cultures integrate the merits of whole plant production with those of microbial fermentation and mammalian cell culture [80, 81]. Plant cell culture inherits most of the advantages of plant-based production systems, particularly the ability to produce complex proteins with correct posttranslational modifications without risk of contamination by human pathogens. Plant cell cultures also can be rapidly propagated in bioreactors as homogeneous suspensions for large-scale production, growing fast in simple synthetic media with doubling times as short as $16 \mathrm{~h}$ [5]. A breakthrough in plant cell culture technology was made in May 2012 by Protalix Biotherapeutics (http://www.protalix.com), an Israel biopharmaceutical company, for a plant cell-produced therapeutic enzyme - taliglucerase alfa - finally approved by the US Food and Drug Administration (FDA) as an orphan drug for Gaucher's disease. Taliglucerase alfa is a hydrolytic lysosomal glucocerebrosidase for intravenous infusion and commercially known as Elelyso ${ }^{\mathrm{TM}}$; it is the world's first plant-made human pharmaceutical and made by Protalix using carrot cells.

Plant cell lines most widely used for recombinant protein production are derived from tobacco (Nicotiana tabacum), particularly cultivar BY-2 (N. tabacum cv. Bright Yellow 2) cells. BY-2 cells are robust and fast growing and can multiply $\geq 100$-fold in a week. They readily undergo Agrobacterium-mediated transformation and cell cycle synchronization [5, 81, 82]. Other commonly used cell lines include rice (Oryza sativa), alfalfa (Medicago sativa), and carrot (Daucus carota). In fact, these cell lines derived from common edible crops may be more favorable than tobacco cells in terms of by-product levels and regulatory compliance [81]. Rice cell suspension cultures are used almost as widely as tobacco BY-2 cells due to availability of the sugar-sensitive $\alpha$-amylase promoter system $(R A m y 3 D)$ [83]. This promoter is induced by sugar starvation and has enabled high-level expression of many pharmaceutical proteins in rice cells, e.g., $\alpha 1$-antitrypsin (rAAT) [33, 83], hGM-CSF [56], interleukin-12 [59], and human serum albumin [60], with highest secreted protein yields reaching $247 \mathrm{mg} \mathrm{L}^{-1}$ for rAAT [33]. While these production levels are impressive, growth rates, and general characteristics and stability of rice cell lines are inferior to those of tobacco BY-2 cell lines; rice cell viability is significantly decreased when cultivated in a sucrose-starvation medium [80].

The major bottleneck to full adoption of plant cell culture technology for commercial purposes has been low productivity with protein yields ranging from 0.01 to $10 \mathrm{mg} \mathrm{L}^{-1}$ [84]. To substantially improve protein expression for commercial success, strategies at both the molecular and at the process development levels are required to maximize efficiency of all stages of the production pipeline $[5,85]$. This is similar to the strategy that has been systematically adopted by the mammalian cell culture industry over the past 25-30 years. Notably, in tobacco BY-2 cells, productivity of M12 mAb was $\sim 8 \mathrm{pg}$ cell $^{-1}$ day $^{-1}$ [86] vs. $20-40 \mathrm{pg} \mathrm{cell}^{-1}$ day $^{-1}$ for Chinese hamster ovary (CHO) cells [79]. Besides low productivity, other major challenges remain including non-mammalian glycosylation, genetic instability, and cell culture scale-up in bioreactors [8, 34, 87]. 


\subsubsection{Hairy Roots}

Hairy roots are generated by infection of plant tissues with Agrobacterium rhizogenes that harbors a root-inducing $(R i)$ plasmid [88]. Similar to suspension cells, hairy roots can be grown in a controlled and sterile environment suitable for cGMP production of pharmaceutical proteins. However, as a more organized organ, hairy roots offer additional benefits, including genotype and phenotype stability and autotrophy for plant hormones [89, 90].

Hairy roots expressing a specific recombinant protein can be readily generated either by infecting stably transformed plants (expressing the target protein) with A. rhizogenes or by infecting wild-type plants with genetically modified A. rhizogenes harboring binary vectors containing the gene of interest [67]. After the first success producing a full-length murine $\mathrm{IgG}_{1}$ in tobacco hairy roots [91], more than 20 recombinant proteins, including reporter proteins (e.g., GUS and GFP), enzymes (e.g., human acetylcholinesterase and tPA), antibodies (e.g., human M12 $\mathrm{mAb}$ and murine 14D9 $\mathrm{IgG}_{1}$ ), antigens (e.g., HBsAg and cholera toxin B surface protective antigen), and cytokines and growth factors (e.g., interleukin-12, hGH, and hEGF), have been expressed in hairy roots $[90,92]$ with protein yields up to $3.3 \%$ TSP of an acetylcholinesterase [93] and $>120 \mathrm{mg} \mathrm{L}^{-1}$ of GFP [68].

Hairy roots also secrete expressed proteins from cultured tissues, termed rhizosecretion [89, 94, 95], offering a simplified, low-cost approach for purification of foreign proteins from inexpensive and well-defined media. Because root tissue is not destroyed for recovery of secreted proteins, a given culture can be used for several cycles of bioproduction. Using an optimized induction protocol for the secretion of M12 mAb from tobacco hairy roots by addition of extra $\mathrm{KNO}_{3}$, $\alpha$-naphthaleneacetic acid, and polyvinylpyrrolidone to the standard MS medium, antibody yield was improved by 30 -fold, yielding $5.9 \mathrm{mg} \mathrm{L}^{-1}$ [62].

The bottleneck to exploiting hairy root technology for commercial purposes has been low protein productivity [90]. Expression systems have been strategically designed to include a strong promoter such as a double-enhanced CaMV35S promoter $(2 \times 35 S)$ [93], a chimeric super-promoter (Aocs, ${ }_{3}$ AmasPmas) [96], and inducible promoters [97]. In addition, the special morphological characteristics of hairy roots including nonhomogeneous growth and highly branched phenotypes present major challenges to culture scale-up in bioreactors [98].

\subsubsection{Moss}

Moss protonema can be suspension cultured in bioreactors to provide another promising platform for producing recombinant products. While plant cells grow on sugar-based media without the need of light, moss is able to grow using light as a sole source of energy, needing only water and inorganic salts as a medium. This greatly reduces production cost and facilitates product recovery from the medium [51]. Moss also can perform complex posttranslational modifications of expressed proteins [99]. Because it relies on differentiated instead of undifferentiated plant cell cultures, moss cultures are genetically stable over long periods of time [100]. The moss Physcomitrella patens, with its genome fully sequenced in 2006 (http://www. cosmoss.org/), is the main species used for bioproduction. 
A wide variety of biopharmaceutical human proteins has been produced in moss including tumor-directed mAbs with enhanced antibody-dependent cell-mediated cytotoxicity (ADCC) [101, 102], keratinocyte growth factor (FGF7/KGF) [77], asialo-erythropoietin (asialo-EPO) [73, 74], $\alpha$-galactosidase and $\beta$-glucocerebrosidase, etc. [77] (www.greenovation.com). See a recent review [103]. Some of the recombinant biopharmaceuticals produced from moss are not only similar to those produced in mammalian cells, but even of superior quality ("biobetters"). For example, moss-made $\alpha$-galactosidase lacks the terminal mannose phosphate and thus is taken up by cells via mannose receptors instead of mannose- 6 phosphate receptors, yielding better pharmacokinetics in Fabry mice [103]. In addition, moss $\mathrm{N}$-glycans are free of core $\alpha-1,6$-fucose, a sugar structure typically present on the N-glycans of mammalian cell-derived proteins. The moss-made IgG lacking this sugar moiety was more efficient in antibody-dependent cell-mediated cytotoxicity (ADCC) than the mammalian cell-made counterparts [101-103].

A unique feature of $P$. patens is that its genome can be readily engineered through gene targeting, a gene replacement strategy based on homologous recombination [51]. The approach has been efficiently used for precision glyco-engineering of moss-produced proteins by knocking out or knocking in certain glycosyltransferase enzymes, allowing for production of humanized glycoproteins [101]. For example, moss mutants were engineered with genes encoding plant typical glycosyltransferases knocked out from the moss genome [72, 74] and further engineered to knock in the gene encoding $\beta$-1,4-galactosyltransferase into the xylosyltransferase or fucosyltransferase locus, respectively [104]. To avoid unwanted potential $O$-glycosylation at the hydroxyproline residues of human proteins, a gene responsible for prolyl hydroxylation was identified and deleted from the moss genome [99]. See recent reviews $[105,106]$.

\subsubsection{Scaling Up In Vitro Systems}

Large-scale cultivation of in vitro systems focuses mainly on cell suspensions and hairy roots. While there are many bioreactors that have been designed for in vitro culture as described in prior reviews that also cite specific examples (e.g., see [107-109]), only a few types of bioreactors seem to be sufficiently scalable for commercial application. These are briefly described below and schematically illustrated in Fig. 1.

While the stirred tank reactor (STR; Fig. 1a) is the industry workhorse for microbial systems, it is not the most ideal option for plant cultures, though as proof of concept some plant cell suspensions have been successfully scaled to $600 \mathrm{~L}[110,111]$. On the other hand, the bubble column, balloon, wave reactors, and variations thereof seem to be more effective thus far for scaling up in vitro cultures. Plant cell suspensions have been grown in nearly all types of liquid-phase bioreactors. The bubble column reactor (BCR; Fig. 1b) is easy to construct in-house with a variety of design variations. Gas enters at the base of the vertical cylinder through a frit forming small bubbles that rise through the chamber, resulting in aeration and mixing; gas vents through a sterile filter at the top. The BCR 
Fig. 1 (a-e) Schematic of main bioreactors used for in vitro cultures a

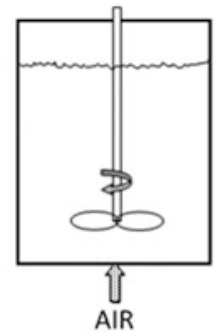

b

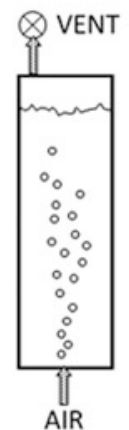

C

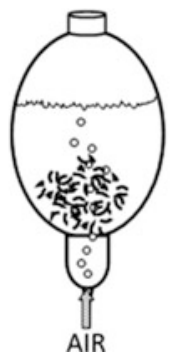

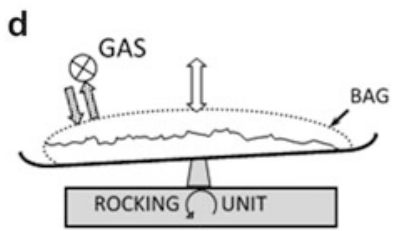

e
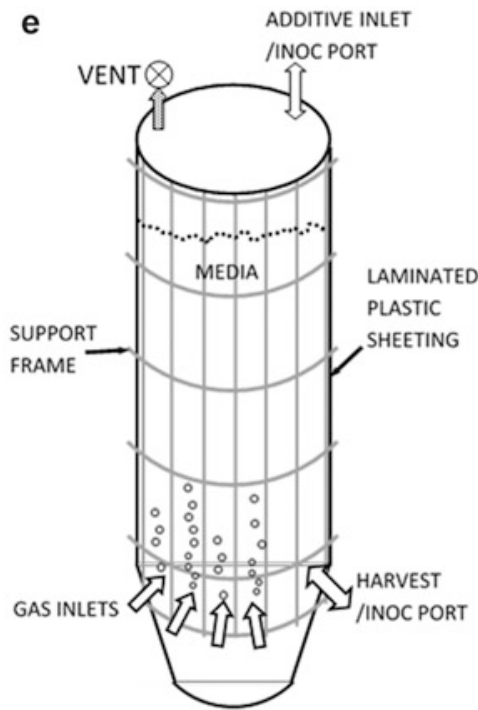

unfortunately suffers from foaming. This led to development of the balloon-type bubble reactor (BTBR) (Fig. 1c) with a broader liquid surface area.

This design alleviated foaming, providing better gas exchange than the BCR. While the BTBR scales from 4 to $500 \mathrm{~L}$, it is constructed of glass, so at large scale it requires a stainless steel superstructure. This greatly increases capital costs and availability of these reactors is limited. The BTBR has been used to culture a wide variety of cell suspensions and hairy roots. See above cited reviews for more in-depth discussion of different requirements for growing cells vs. hairy roots including many species examples.

The wave bioreactor (Fig. 1d) is a horizontal, transparent plastic bag, seated on a slowly rocking platform that through wave action within the bag provides good agitation. With gas input into the headspace above the large surface area of the liquid in the bag, there is also good gas exchange. Although the wave reactor is being commercially used, it unfortunately scales horizontally with a relatively large 
footprint compared to the vertical reactors, for example, that used by Protalix as subsequently discussed.

Other than the glass balloon reactor, plastic single-use disposable culture chambers are also becoming the norm. These can include isolated bags or liners within a supporting superstructure. A vessel with a plastic liner was designed, demonstrated, and patented (US 6,709,862 B2) as versatile and functional some time ago by the Curtis lab [112]. For example, the SB200-X (OrbShake, Kühner AG) is comprised of a large $200 \mathrm{~L}$ cylindrical vessel with an inner disposable bag that sits on a platform and is orbitally shaken. This reactor has shown some success in cultivation of recombinant BY-2 tobacco cells for production of human M12 mAb. Yields of 300-387 $\mathrm{g} \mathrm{FW} \mathrm{L}^{-1}$ and $\sim 20 \mathrm{mg} \mathrm{L}^{-1} \mathrm{M} 12$ were equivalent to yields obtained in shake flasks [113]. Single-use cultivation chambers obviate cross contamination of products or cultures from run to run and are less capital intensive, and because there is no need for sterilize in place (SIP) or clean in place (CIP) plumbing, they also have simpler accommodation requirements [114]. Plastics approved for use by FDA include polypropylene, polystyrene, polyethylene, polytetrafluoroethylene, or ethylene vinyl acetate, facilitating regulatory approval of the overall production process [114].

Moss can also be grown in many of these same bioreactors [103]; however, if light is needed for autotrophic growth, then a photobioreactor is required along with attendant challenges that are further addressed in Sect. 3.2.3. Indeed, successfully grew $P$. patens under GMP-certified conditions in 100 and $500 \mathrm{~L}$ wave bioreactors under artificial illumination, so for high-value products smaller volume reactors may be reasonable. If moss could be grown heterotrophically, then the same bioreactors described for cells and hairy roots could be employed. Nevertheless, Greenovation Biotech GmbH (www.greenovation.com/) is using its BryoTechnology ${ }^{\mathrm{TM}}$ platform to commercialize recombinant biopharmaceuticals. Several therapeutic enzymes targeted for enzyme replacement therapies, such as $\alpha$-galactosidase, $\beta$-glucocerebrosidase, and complement factor $\mathrm{H}$ are under preclinical or Phase I development (www.greenovation.com/).

Modularity is a valuable tool in modern bioprocess design. Implementation of multiple, smaller scale, e.g., $\leq 500 \mathrm{~L}$, reactors is useful in production facilities because it provides the ability to scale in response to demand, minimizes risks of loss due to contamination, and is less capital intensive. An example of a successfully scaled up commercial cell suspension culture is that by Protalix using carrot cells engineered to produce recombinant glucocerebrosidase as a replacement therapy for managing Gaucher's disease, taliglucerase alfa $\left(\right.$ Elelyso $\left.^{\mathrm{TM}}\right)$ manufactured by Pfizer. The large-scale patented [115] cultivation system (ProCellEx ${ }^{\mathrm{TM}}$ ) for growing these carrot cells uses $\geq 400 \mathrm{~L}$ vertical conical-shaped plastic culture bags similar in design and operation to a BCR with aeration inlet ports near the bottom of the bag and a gas vent/regulator at the top to help maintain bag inflation (Fig. 1e). Rising gas bubbles from the gas inlet ports provides culture agitation and mixing. The large suspensionfilled bags have a grid-like superstructure providing external support (Fig. 1e). The system is modular, thereby allowing cultivation and harvest cycles; a central unit provides aeration and nutrients [116]. Inoculant and culture media are provided to 
each reactor, and excess air and waste gases are removed. All units are housed in a clean room. Schematics and details of the reactor technology are in US Patent 2010/ 0112700 A1.

\subsection{Aquatic Plants}

Some aquatic plants also are promising bioproduction platforms, including duckweed and microalgae. Many functional industrial enzymes or human therapeutics have been expressed in duckweeds or microalgae at lower cost than in vitro systems [85].

\subsubsection{Duckweed}

Duckweed, the common name for Lemnaceae, is a monocot plant family consisting of four major genera: Lemna, Spirodela, Wolffia, and Wolffiella. Duckweed is propagated clonally without the need for pollen or seeds, which simplifies line management, propagation, and the process feed stream [32, 117]. Duckweed is safe, fast growing in simple inorganic media (doubling time $\geq 36 \mathrm{~h}$ ), capable of making complex proteins, and easy to grow and harvest and has a high protein content (up to $45 \%$ dry weight) $[85,118]$. Cultivation only requires inexpensive upstream facilities and is very scalable. The absence of pollen or seeds also makes duckweed environmentally safer than other transgenic flowering plants. Moreover, duckweed is edible, offering an attractive system for oral delivery [119, 120].

Duckweed can be transformed using either biolistics or A. tumefaciens. Efficient nuclear transformation protocols for two species of duckweed, L. gibba and L. minor, were established in 2001 [121], and $>20$ recombinant proteins were produced with expression levels up to $25 \%$ of TSP [32]. Products include industrial enzymes, e.g., E1 endoglucanase [122], and many therapeutic proteins, e.g., mAb [123], plasminogen [124], interferon $\alpha 2$ [125], vaccine antigen avian influenza including H5N1 hemagglutinin [126, 127], and M2e peptide [117].

In 1997, US-based Biolex, Inc. developed the duckweed (Lemna)-based expression (LEX) system and successfully expressed at least 12 therapeutic proteins, including small peptides, mAbs, and large multimeric enzymes [2]. However, in 2012, Biolex's technology was sold to Synthon, a Netherlands-based pharmaceutical company, and interest in the LEX system subsided; research is currently focused on wastewater treatment (phytoremediation) and biofuel production.

\subsubsection{Microalgae}

Microalgae integrates the merits of microbes, including rapid growth and ease of culture with those of higher plants in performing posttranslational modification and photosynthesis, thereby offering another promising platform for cost-effective production of recombinant proteins [128-130]. Microalgae have a very simple structure, grow in simple media, and produce large amounts of biomass with short life cycles [131]. Downstream purification of proteins from microalgae is similar to yeast and bacterial systems and thus is generally less expensive than from whole plants 
[132]. Many species also are generally regarded as safe (GRAS) for human consumption, thus providing a potential platform for oral delivery.

Both nuclear and chloroplast genomes of microalgae can be transformed for expressing heterologous proteins. However, due to the nuclear silencing, nuclear transformants generally accumulate less recombinant protein than chloroplast transformants [129]. Thus, the chloroplast expression system is currently regarded as more feasible for commercial production [128]. The disadvantage of chloroplast transformation is that this organelle lacks posttranslational modification capability, e. g., glycosylation [130]. However, this may provide a benefit for antibodies produced in chloroplasts, because glycan-free antibodies do not activate the immune system in humans [133, 134].

Chlamydomonas reinhardtii is the unicellular green algal species on which the majority of genetic engineering has been performed [128, 135, 136]. This alga grows fast with doubling time of $\sim 10 \mathrm{~h}$, supports easy nuclear and chloroplast transformation, and can be cultivated either photoautotrophically or with acetate as a carbon source [85]. A variety of high-value recombinant proteins, including antibodies, vaccines, growth factors, and industrial enzymes have been produced in microalgae from either nuclear or chloroplast transformation, as documented in several recent reviews [131, 137, 138]. Most of these were produced in the chloroplast of C. reinhardtii, but some were produced in other species, such as Dunaliella salina and Phaeodactylum tricornutum.

Development of economically viable bioproduction is still hampered by a lack of effective and consistent transformation methods for a wider variety of species, as well as low (nuclear expression) or inconsistent (chloroplast expression) recombinant protein yields [129]. PhycoBiologics (www.phycotransgenics.com) is currently attempting to commercialize microalgal production with indoor photobioreactors yielding axenic algae with $>20 \%$ of TSP in the chloroplast (www.phycotransgenics. com) [132].

\subsubsection{Scaling Up Aquatic Systems}

Duckweed, moss, and microalgal aquatic species require light for autotrophic growth to achieve high biomass yields, which in turn affects product yields. Autotrophic cultivation requires either sunlight or significant artificial lighting intensity that is in close proximity to the cultured cells. Options include open systems such as ponds and raceways and closed systems such as tubular or plate photobioreactors. While possibly suitable for low-value commodity or industrial products, for products requiring strict GMP compliance, open systems are not recommended because they can be contaminated with a variety of other species and particulates and do not provide production source material consistency. There are also issues regarding environmental release of genetically modified species grown in an open pond. Although tubular or flat plate photobioreactors would seem best, these also have challenges. While the development of more cost-effective LED lighting is now available, these reactors cannot exceed certain culture depths. As culture density increases, light does not penetrate beyond several centimeters, and thus as the culture increases in density, growth decreases significantly. Although cGMP industrial 
facilities now exist for moss cultivation, to our knowledge, there is none yet for microalgae [31]. For a more in-depth discussion of photobioreactor designs and limitations, see the review by $\mathrm{Xu}$ et al. [139].

\subsection{Whole Plants: Stable and Transient Expression Systems}

Whole plant expression still dominates plant-based bioproduction platforms and uses either transient expression via viral or nonviral vectors or stable transformation with transgenes targeted to either the nuclear or chloroplast genome. Stable transformation advantages include (1) a heritable transgene, permitting establishment of seed stock for future use, and (2) protein production scalable to field production. However, establishing and characterizing stable transgenic lines can be costly and time consuming. Other challenges include gene silencing, position effects, and GMO environmental concerns [132, 140].

When establishing stable transgenic plant lines, choices are often made regarding the gene integration site (nuclear vs. plastid), the subcellular compartment for recombinant protein accumulation (e.g., cytosol, apoplast, endoplasmic reticulum, and vacuole), and the plant tissue expression target (leaves vs. seeds). Decisions depend on a variety of considerations, including posttranslational modifications needed for protein functionality, stability of the expressed foreign protein in the plant host, desired expression levels of product, and downstream purification costs, as well as size and cost constraints of the product market [85, 95].

\subsubsection{Stable Expression: Leaf Based}

Leaf tissues of nonfood crops have traditionally been used as a viable expression platform for either research or production purposes. The first plant-produced recombinant protein, an immunoglobulin, was expressed in transgenic tobacco leaves [141]. Tobacco has emerged as the leading plant species for leaf-based protein expression [142] because it produces high biomass yields ( $\sim 300$ tons per acre), is genetically well studied, and is readily amenable to genetic engineering [15]. Importantly, tobacco is a nonfood, nonfeed crop, which minimizes regulatory barriers by eliminating the risk of plant-made recombinant proteins entering the food supply [143]. The first clinical trial of a plant-produced biopharmaceutical was the secretory antibody variant of Guy's 13 produced in field-grown tobacco leaves by Planet Biotechnology Inc. [144]. Besides tobacco, other leafy crops, e.g., lettuce, alfalfa, and clover, have also been exploited as an expression platform. Alfalfa is advantageous because it is a perennial that fixes nitrogen and displays notable homogeneity of N-glycosylated recombinant proteins [85, 145].

Both leaf nuclear and plastid genomes have been targeted for integration of heterologous genes. The choice of gene integration site is generally dictated by the posttranslational requirements of the target proteins. Nuclear integration is necessary for expression of functional glycoproteins, such as EPO and tPA, that need proper processing in the endo-membrane system [35]. Thus far $>100$ functional proteins have been successfully expressed in leaves with nuclear transformation. These 
include mAbs [141, 146-148], vaccines [149], cytokines [150, 151], and industrial enzymes $[152,153]$. See reviews $[3,84,132,154]$. Unfortunately, low copy of gene integration, gene silencing, and proteolytic degradation in the aqueous environment of leaves resulted in $<1 \%$ TSP $[155,156]$.

Each plant cell contains an average of 50-100 chloroplasts, and each chloroplast contains $\sim 100$ copies of its genome, thus the chloroplast enables thousands of copies of a given transgene to be expressed [157-159]. With chloroplast transformation, accumulation of recombinant protein up to $70 \%$ of the total leaf protein has been achieved [160]. See the special issue on Chloroplast Biotechnology in Plant Biotechnology Journal (June 2011). A wide range of proteins, ranging from very small antimicrobial peptides or hormones to very large viral or human proteins, have been successfully expressed in plant chloroplasts [161]. Except for exceptionally highlevel expression, therapeutic proteins accumulated in the chloroplasts of lyophilized plant cells can be stored for several months or years without a decrease in their functionality, thereby eliminating costs of cold storage and transportation [162]. However, because the chloroplast does not support many important posttranslational modifications desired for expressing complex proteins, this technology is limited to production of proteins whose functions are independent of glycosylation. Another disadvantage of chloroplast transformation is the difficulty of transforming many important crop plants using current methods [163].

Chloroplast transformation also provides a unique bioproduction system for oral medicines [164]. When a pharmaceutical protein is accumulated in plant leaves, the plant cell wall can protect the protein drug from acids and enzymes in the stomach via bioencapsulation after oral delivery. However, microbes residing in the human gut have evolved to break down the plant cell walls to release the target protein [164]. If a transmucosal carrier (receptor-binding protein) such as cholera toxin subunit B (CTB) and heat-labile toxin subunit B (LTB) that binds to GM1 receptors is fused to the protein drug, it will efficiently cross the intestinal epithelium and be delivered to the circulatory or immune system [161]. Several drugs have advanced to the clinic, including glucocerebrosidase for treating Gaucher's disease [12], clotting factor IX for treating hemophilia B [165], myelin basic protein for treating Alzheimer's disease [160], acid $\alpha$-glucosidase for treating Pompe disease [166], and, most importantly, a variety of oral vaccines for treating infectious diseases [158, 167]. See recent reviews [164, 168, 169].

Limitations of leaf-based platforms compared to seeds are the short shelf life of leafy tissue and the high variability of the production system. Plant leaves degrade faster upon harvest and must be processed immediately to ensure product stability and quality. Product yields in field-grown materials can be highly variable due to environmental changes (both biotic and abiotic). Finally, large-scale, regulatorycompliant disposal of transgenic biomass waste may have volume and cost implications [85].

\subsubsection{Stable Expression: Seed Based}

Recombinant protein expression targeted to plant seeds can overcome the major limitations associated with leaf tissue: protein stability and storage [170, 171]. Plant 
seeds are naturally suited to produce and store proteins. High protein content (7-10\%), low protease activity, and low water content make seeds an attractive alternative bioproduction platform $[155,156]$. Antibodies or vaccines expressed in cereal seeds remained stable at ambient temperatures for years [85, 172]. In addition, edible seeds such as maize and rice have GRAS, status making them particularly suitable for developing oral vaccines that can be administered as flakes or flour with minimal purification [173]. In the past decade, significant advances have occurred using seeds as bioreactors including the commercialization of the first plant-derived recombinant protein, avidin, produced in maize seeds [170].

Cereal seeds, e.g., rice, wheat, barley, soybean, and maize, are commonly used as expression hosts [174]. Other typical production platform seed crops include legumes (pea, cowpea, and soybean), oil crops (canola and safflower), tobacco, and Arabidopsis. Stable expression yields up to $10 \%$ of total seed proteins have been achieved $[170,175]$. Products include therapeutic proteins such as antibodies [176], vaccines [177], and cytokines [178]; industrial enzymes such as trypsin [179], phytase [180], and cellulase [181]; and biopolymers such as spider silk protein [182]. See recent review [173].

Maize seeds are the most widely used host for commercial therapeutic proteins and industrial enzymes [173]. Compared to other cereals, maize has a larger grain size, a higher proportion of endosperm ( $\leq 82 \%$ of the seed), and a higher biomass yield per hectare at lower production costs [173, 183, 184]. Many industrial enzymes, including GUS, cellulase, laccase, and trypsin, have been successfully produced in maize seeds and marketed [27, 184]. Therapeutic proteins such as the HIV neutralizing antibody 2G12 [185], influenza virus H3N2 nucleoprotein [186], and $\alpha$-galactosidase [187] in maize seeds were produced cost-effectively with simple downstream purification processes. Other seed-based platforms in commercial development include rice seed-produced human transferrin [188] by US-based Ventria Biosciences (www.ventria.com/) and barley grain-produced endotoxin-free growth factors and cytokines (Orfeus ${ }^{\mathrm{TM}}$ expression system) [189] by Iceland-based ORF Genetics Ltd. (www.orfgenetics.com/).

Seeds from some oil crops such as safflower and rapeseed have been used to develop a novel "oleosin-fusion" bioproduction platform, in which recombinant proteins are expressed as a fusion with oleosin, an endogenous protein that localizes within oil bodies of rapeseed and safflower [190, 191]. Fusion proteins accumulated in the oil bodies are easily separated in the lipid fraction from the bulk seed homogenate. SemBioSys Genetics, a Canadian biotech company, was developing and commercializing this technology for the low-cost "biosimilar" insulin [85], but operations ceased in 2012 due to financial problems.

Although a seed-based platform has many positive attributes, major hurdles still exist. Compared to the leaf-based platform, seeds have a relatively lower biomass and high possibility of gene leakage into the environment via the seed or from pollen dispersal $[15,192]$. There is strong reluctance among scientists, regulators, and the general public to use seeds of major crops (e.g., maize, rice, and wheat) for recombinant protein production because of the possibility of contaminating the food chain [192]. Considerable time is also required to create high-expressing 
transgenic plant lines [155]. However, the stability of foreign proteins, post-harvest processing, and overall cost makes the seed-based platform suitable for many recombinant proteins produced on a large scale [193].

\subsubsection{Transient Expression}

Transient expression is achieved either by epichromosomal expression of A. tumefaciens directly infiltrated into plant tissues (agroinfiltration) or by viralbased expression vectors [194, 195]. During transient expression, foreign genes are typically introduced into leaves of plants by vacuum infiltration of Agrobacterium containing genes of interest in an expression vector [85]. Recombinant protein production within the plant tissues (usually leaves) can be initiated quickly, within $24 \mathrm{~h}$, continuing for several days depending on vector and target protein. Because a high copy number of foreign genes is introduced into each plant cell and free of "position effect" on gene transcription, the protein yields are usually higher in transient than in stably expressed plants [196]. Since there is no transgenic plant created, this also addresses regulatory issues and public concerns for GMO plants [197]. As a result, transient expression has been increasingly used for production of biopharmaceuticals, in particular, antigen vaccines and antibodies [195, 197].

$N$. benthamiana is the most common host plant for transient expression because it is amenable to genetic transformation and rapidly yields large amounts of biomass from seeds for scale-up production [198]. Potato, green pea, Arabidopsis, lettuce, and other Nicotiana species (e.g., $N$. debneyi, $N$. excelsior, and $N$. simulans) also serve as alternative hosts for transient expression [85]. There are two basic strategies for introducing transgenes into host plant cells for bioproduction: nonviral vector based or viral mediated [199, 200]. Nonviral vector-based expression using common plant expression vectors enables rapid accumulation of recombinant proteins in plant leaves, typically $2-4$ days post-infiltration, with protein yields of $0.1-200 \mu \mathrm{g} \mathrm{g}^{-1}$ FW [85]. The viral-mediated expression process takes $\sim 2$ weeks for protein expression, but generally produces higher levels of recombinant protein up to $5.0 \mathrm{mg} \mathrm{g}^{-1}$ FW GFP [201]. Some effective viral vector-based expression platforms include Geneware $^{\circledR}$ (Kentucky BioProcessing LLC) and magnICON ${ }^{\circledR}$ (Icon Genetics) based on a tobacco mosaic virus (TMV) RNA replicon and the geminiviral expression system based on a bean yellow dwarf virus (BeYDV) DNA replicon (Arizona State University) [202-204].

Transient systems also provide the ability to simultaneously co-express several genes to produce complex proteins, such as antibodies, viruslike particles (VLP), and other multichain proteins [195]. Numerous therapeutic proteins, especially those addressing sudden viral epidemics (e.g., an outbreak of Ebola, severe acute respiratory syndrome, or influenza pandemic) have been successfully produced by a transient expression system [132, 205, 206]. For example, Mapp Biopharmaceutical Inc. (San Diego, CA) used the geminivirus technology to transiently express the humanized antibodies MB-003 (Mapp) and ZMab in tobacco leaves (http://mappbio. com/z-mapp/). An optimized cocktail combining the best components of the MB-003 and ZMab was ZMapp ${ }^{\mathrm{TM}}$, which cured 100\% of Ebola-infected rhesus macaques primates [207, 208]. In another example, plant-produced influenza 
vaccine candidates, such as VLP antigens against avian flu (H5N1) virus and swine flu (H1N1) virus, were developed by the Canadian biotech company Medicago Inc. (Quebec, Canada) and have undergone Phase I and II clinical trials with positive results (http://medicago.com/pandemic-flu/). Plant-produced influenza vaccines are regarded as quicker to develop and potentially cheaper than egg-produced vaccines. Many other therapeutic proteins reportedly produced by the transient expression platform include IgG and IgA antibodies [209, 210], vaccine antigens against malaria, influenza and HIV [211-215], and therapeutic enzymes treating lysosomal storage diseases [216]; see recent reviews [140, 195, 217, 218].

Transient expression is easily applied to industrial scale for mass production of recombinant proteins. Milligram to gram quantities of target proteins can be rapidly produced in weeks to allow animal and clinical testing. Several plant biotech companies, including Kentucky BioProcessing LLC (Owensboro, KY), Medicago Inc. (Quebec, Canada), Fraunhofer CMB (Newark, DE), Mapp Biopharmaceutical Inc. (San Diego, CA), and iBio Biotherapeutics (Bryan, TX), have developed cGMP manufacturing facilities for biopharmaceuticals using vacuum agroinfiltration of $N$. benthamiana [219]. A major disadvantage of the transient system is the necessity of harvesting at a particular time. If using the product in humans or animals, an additional purification step to remove endotoxins derived from the infiltrated Agrobacterium is required [85]. Transient expression systems have been continuously optimized in the past decade for rapid, high-yield, and large-scale production of recombinant proteins, which expedites the acceptance of this production platform for the commercial production of a broad range of biopharmaceuticals.

\subsubsection{Scaling Up Whole Plant Systems}

While field production of plants provides a distinct advantage given its apparent low cost, considerations of weather, pests, and seasonal effects on productivity will increase costs. Similarly there are concerns regarding the risk of unintended environmental contamination of native gene pools by genetically modified field crops. An alternative is the use of controlled environment agriculture (CEA), where the transgenic crop is grown in glasshouses. Of course this increases production cost substantially, but may be worthwhile if there is high product value, e.g., for a therapeutic. CEA is not subject to seasonal variation, providing greater control over cultivation conditions and thus the quality of the crop and its contents. A number of companies have developed more or less automated cultivation systems under glass where product quality is maintained and aseptically handled in its final form. Medicago has developed such a CEA system whereby they hope to produce a number of different products via transient expression in tobacco. The production system begins after there is a synthesized gene of interest (GOI) from, for example, a virus. Then young $N$. benthamiana tobacco plants grown in pots in contained greenhouses are handled robotically including the vacuum infiltration step. Large pallets of plants are inverted into a solution containing the GOI and vacuum infiltrated. Afterward the inverted plants are drained and rotated back into vertical position and then moved into another more stringent culture facility for a 4-6-day 
incubation for gene expression and protein synthesis. Plants are subsequently moved to a harvesting area where leaves are stripped by hand and then extracted. Using methods applicable to any other clinical grade in vitro or microbial product, the target protein is purified. The process is documented in this video: https://www. youtube.com/watch? $\mathrm{v}=1 \mathrm{Ak} \_\mathrm{HkFi} 9$-s.

There are different GMP concerns for products produced from whole plants that extend beyond those for products produced from in vitro cultures (Fischer et al. 2012). Guidelines drafted in the USA by USDA and FDA exist to cover all platforms described herein (FDA-USDA 2002 http://www.gmp-compliance.org/guidemgr/ files/BIOPLANT.PDF ). These include selection of a crop species platform suitable for industrial production; in industry a diversity of platforms is problematic because of the need for consistent and stringent regulatory compliance, especially for therapeutics. Subsequently there should be an early stage determination of field vs. CEA cultivation. Similar to in vitro or microbial production, master seed or tissue banks must be established and maintained to provide batch to batch consistency. Isolation of GM plant material, controlled seed stock, APHIS/BRS permits for field-grown plants, appropriate confinement for transport of source plant material from field/ greenhouse to production facility, control of harvested material and its transfer to the processing facility, waste biomass control, storage control, are all needed for production operations that can be validated.

Whole plant production can be further streamlined through second generation propagation via shoot regrowth from a retained axillary bud on the rootstock after harvesting the initial shoot Kim [220]. Functionality and yields of protein in harvested leaves from three successive harvests remained relatively consistent. Time required for seed production and germination and second and third generation shoots required $>50 \%$ less time to harvest vs. initial planting. Another obvious alternative strategy would be rooting of clonal cuttings of transgenic plants to rapidly scale-up whole plants. Such a strategy should also minimize time to harvest as there is no need to generate seed or use in vitro micropropagules.

\section{Commercialization Status and Outlook}

Since conceptualization in 1989, the plant molecular farming industry has grown rapidly. While some plant-made industrial proteins/enzymes (e.g., avidin, GUS, and trypsin) and one plant cell-made pharmaceutical for human use (Elelyso ${ }^{\mathrm{TM}}$ ) have been commercialized, many are in various developmental stages. Examples of some successful plant-produced products, either on the market or in commercial development, are listed on the Molecular Farming website last updated in March 2014 (http://www.molecularfarming.com/PMPs-and-PMIPs.html), or in some recent reviews [50,132, 221, 222]. The major biotech companies involved in research and development of plant-produced protein products that are still in business are listed in Table 3. These companies include the representatives of the very first commercial ventures (Large Scale Biology Corp., Planet Biotechnology, Ventria 


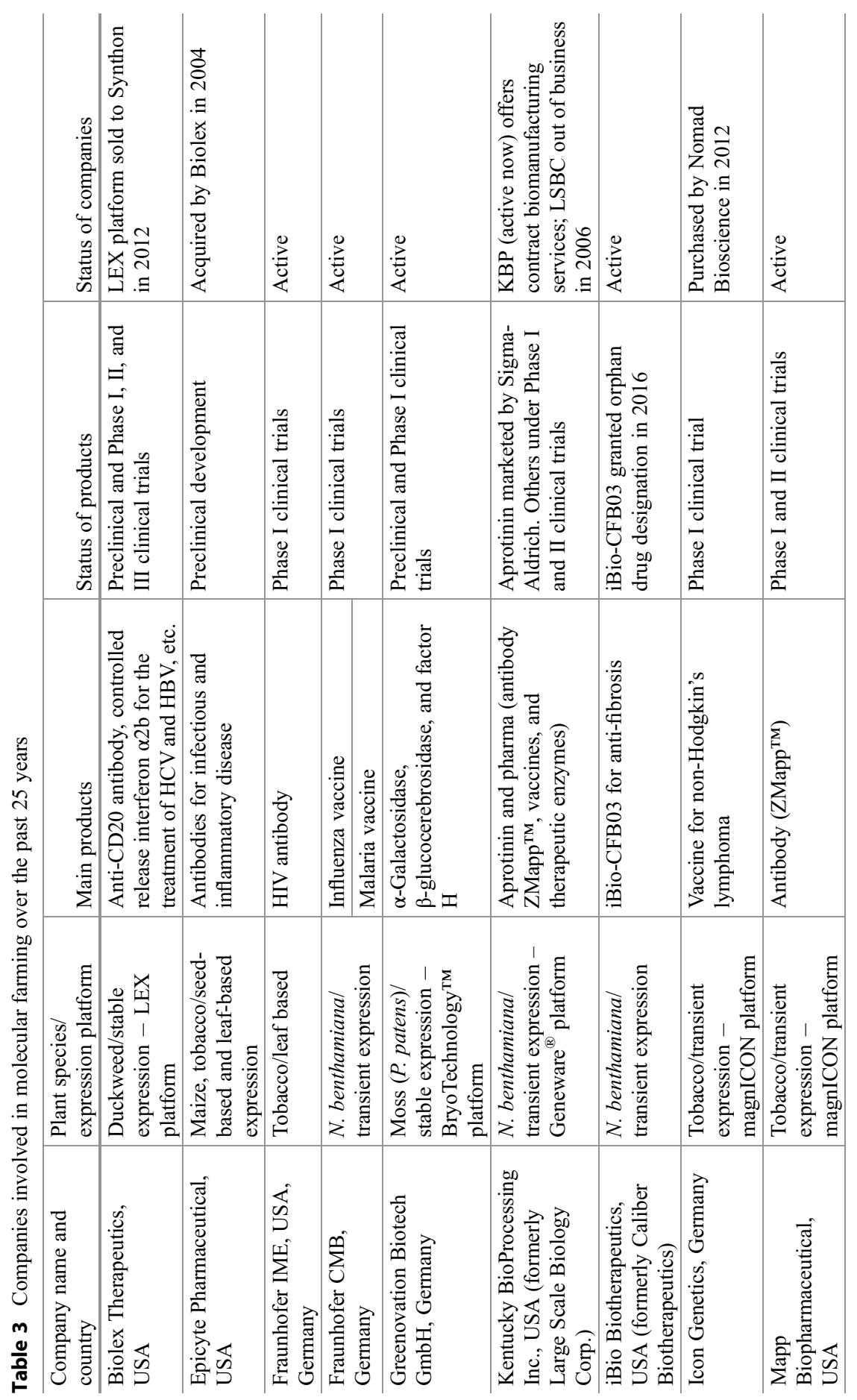




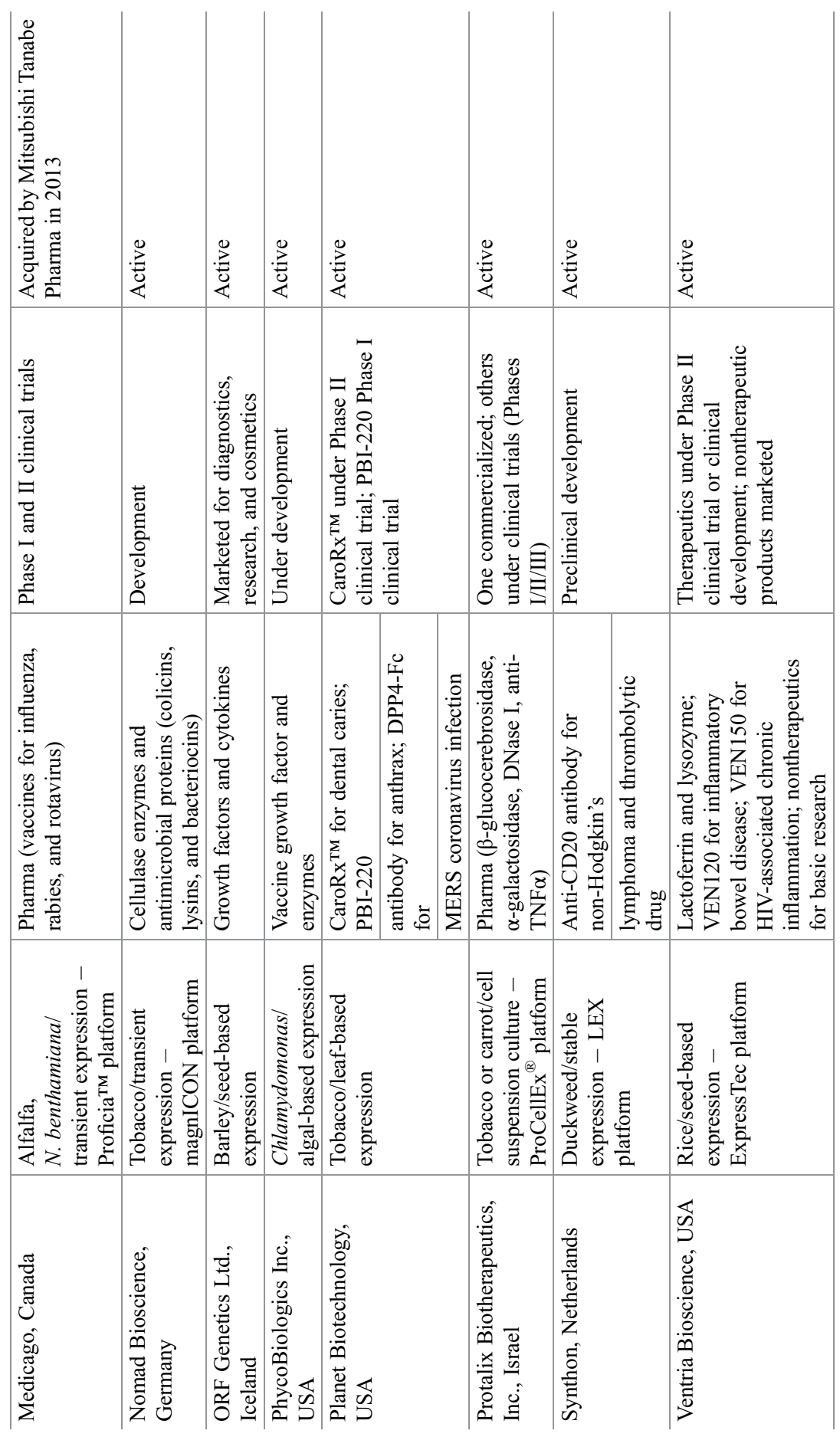


Bioscience, SemBioSys Genetics, and Protalix), companies established in the mid-1990s (Epicyte, Medicago, Biolex, Icon Genetics, Greenovation, and ORF Genetics), and companies that emerged from the earlier pioneers (Mapp Biopharmaceutical, Kentucky BioProcessing, and Nomad Bioscience) [219]. In 1999, Large Scale Biology Corporation (Owensboro, KY), now Kentucky BioProcessing, designed and opened the first cGMP manufacturing facility for production of recombinant therapeutics by using the plant-virus transient expression system Geneware $^{\circledR}$. For plant transient expression systems (vacuum infiltration of $N$. benthamiana) to rapidly manufacture vaccines in response to epidemics and outbreaks, the US Defense Advanced Research Projects Agency (DARPA) sponsored four pilot-scale cGMP manufacturing facilities in the USA, including Fraunhofer CMB (Newark, DE), Kentucky BioProcessing (Owensboro, KY), Medicago (Durham, NC), and Caliber Biotherapeutics (now iBio Biotherapeutics, Bryan, TX) [206]. So far, iBio Biotherapeutics runs the world's largest plant-based vaccine production facility with the capacity to process over $3500 \mathrm{~kg}$ of plant biomass per week (http://www.ibioinc.com/). With the advance in both technologies and manufacturing facilities, plant molecular farming is now reaching the stage at which it may challenge established microbial and mammalian bioproduction systems. Commercialization status of the three classes of plant-made recombinant products is briefly described as follows.

\subsection{Plant-Produced Industrial Proteins/Enzymes}

Due to ProdiGene's pioneering work on the development and commercialization of several hydrolases including avidin, GUS, lysozyme, trypsin (TrypZean ${ }^{\mathrm{TM}}$ ), and aprotonin (AproliZean ${ }^{\mathrm{TM}}$ ) in the late 1990s [3, 7, 223, 224], plant-made industrial proteins spearheaded commercialization over the other two classes of proteins [85]. However, ProdiGene went bankrupt in 2002 due to mishandling US field tests of maize genetically modified to make pharmaceutical products and received more than a $\$ 250,000$ fine from USDA. Since then, efforts on commercializing plant-made industrial proteins have declined. Most of the research is now focused on production of biomass-degrading enzymes for the biofuel industry, e.g., cellulase, hemicellulase, xylanase, ligninase, $\alpha$-amylase, and laccase [181, 225-227]. For example, an Arkansas-based start-up company, Infinite Enzymes (http://www. infiniteenzymes.com/), has been developing a cost-effective maize seed production system for cellulase enzymes for cellulosic biofuel production. It is noteworthy that in 2011, a transgenic variety of maize expressing thermostable $\alpha$-amylase was approved by the USDA for commercial use as an improved biofuel feedstock. This transgenic maize line, marketed as Enogen ${ }^{\mathrm{TM}}$, was developed by Syngenta (http://www2.syngenta.com/en/index.html) to produce - within the kernel - an enzyme needed to break down starch for biofuel production. However, it sparked a controversy not only from anti-GMO organizations but also from some biotech supporters because of environmental and human health issues [228]. 


\subsection{Plant-Produced Therapeutic Proteins}

This class of protein products has attracted the most interest in research and development in molecular farming. More than 20 plant-made pharmaceuticals have been placed in preclinical or clinical trials to date [132], and specific product examples are further discussed.

\subsubsection{Antibodies}

Production of therapeutic antibodies (plantibodies) is of great interest for the plant molecular farming industry [209]. Although none to date has been approved by pharmaceutical regulators, several plant-made antibodies have made it to human clinical trials. For example, CaroRx ${ }^{\mathrm{TM}}$, a secretory $\operatorname{IgA}(\mathrm{SIgA})$ plantibody produced by Planet Biotechnology Inc., was the world's first clinically tested antibody for preventing adhesion of decay-causing bacteria to the tooth surface. Since 1999 CaroRx ${ }^{\mathrm{TM}}$ was subjected to Phase II clinical trials (topical) for dental caries in the USA under an FDA-approved Investigational New Drug Application [229], but was discontinued in early 2016. ZMapp ${ }^{\mathrm{TM}}$, a cocktail of three mAbs produced in tobacco leaves by Mapp Biopharmaceutical Inc. to combat the 2014 Ebola virus outbreak in Africa, underwent clinical Phase I and II trials in 2015 in the USA, Liberia, Sierra Leone, and Guinea, sponsored by the National Institute of Allergy and Infectious Diseases (NIAID) [132]. In September 2015, ZMapp ${ }^{\text {TM }}$ was granted a fast-track status by the US FDA (http://mappbio.com). Although it has not yet received final approval by FDA, to date, ZMapp ${ }^{\mathrm{TM}}$ is the only drug that has been effectively used to treat patients infected with the Ebola virus [206]. In addition, a tobacco-derived HIV neutralizing antibody 2 G12, produced by an EU funded project, Pharma Planta, recently completed a Phase I clinical trial [147].

\subsubsection{Vaccine}

Although several plant vaccines, for either animals or human, are now in clinical trials with encouraging results [229, 230], none thus far has been commercialized. Despite Dow AgroSciences receiving the world's first regulatory approval by USDA in 2006 for a tobacco cell-produced vaccine against Newcastle disease virus in chickens, it only remained a proof of concept; Dow AgroSciences never intended to market the product [231]. However, since the scale of animal vaccination is so large, plant-based systems may represent the only cost-effective production platform on a scale for which other (non-plant-based production) methods are not competitive. Furthermore, plant-made veterinary vaccines, such as those made in seeds, fruits, and leaves, can be orally delivered as part of the animal feed, thus offering great convenience and economy in immunizing large populations of animals on farms [232]. In terms of commercialization potential, regulatory approval for the plant-made veterinary vaccines can be significantly less onerous than that for human vaccines [233]. Therefore, the most likely near-term possibilities for commercialization of plant-derived vaccines will be the veterinary products. Key examples of plant-produced vaccines tested in target animal species, including those against avian influenza, foot-and-mouth disease, Newcastle disease, diarrheal disease caused 
by enterotoxigenic E. coli, porcine reproductive and respiratory syndrome, and swine transmissible gastroenteritis, are listed in recent reviews [231, 234]. These antigens were expressed in potato tubers, rice seeds, corn seeds, and $N$. benthamiana leaves. With continuing efforts to optimize the bioproduction platform, successful commercialization of plant-made veterinary vaccines is imminent.

The recent outbreak of avian and swine flu spurred development of seasonal and pandemic influenza vaccines. Medicago developed the Proficia ${ }^{\mathrm{TM}}$ technology, a transient plant expression platform for rapid and high-yield production of vaccines and antibodies, in particular, the viruslike particle (VLP)-based antigen (VLPExpress $^{\mathrm{TM}}$ platform). Their products are at various stages of development. For example, the vaccine candidates against various influenza strains (e.g., H5N1 and H1N1) in Phase I and II human clinical trials were found safe and well tolerated, and potency was among the most effective of the industry (www.medicago.com). Mitsubishi Tanabe Pharma (Osaka, Japan) acquired Medicago in 2013 and announced that its tobacco-based flu vaccine could hit the market by 2018 or 2019. Fraunhofer CMB (Newark, DE) developed another type of plant-made VLP vaccine, Pfs25-VLP, for blocking malaria transmission [236]. The Phase I trial of Pfs25-VLP was completed in 2016 (https://clinicaltrials.gov/ct2/show/ NCT01867463). One of the unique features of plant-made vaccines is that plants not only serve as the production "bioreactor" but can serve as the delivery vehicle for oral vaccines [236, 237]. Professor Charles J. Arntzen, a pioneer in plant-made oral vaccines at Arizona State University, has been developing plant-based oral vaccines including HBsAg (Phase I in lettuce and Phase II in potato), Vibrio cholerae vaccine, heat-labile toxin B subunit of $E$. coli, and the capsid protein of Norwalk virus (all are Phase I in potato) $[1,2,85]$.

\subsubsection{Therapeutic Enzymes}

Therapeutics targeted for enzyme replacement therapies have been mainly developed by the Israel biopharmaceutical company Protalix Biotherapeutics. They developed and commercialized several recombinant therapeutic proteins through their ProCellEx ${ }^{\circledR}$ plant cell-based expression system (www.protalix.com). In 2012 Protalix commercialized Elelyso ${ }^{\mathrm{TM}}$ (taliglucerase alfa for injection), the very first plant-made therapeutic ever approved by the FDA for human use and has been marketed in the USA, Canada, and many Latin American countries (Uplyso ${ }^{\mathrm{TM}}$ in Latin America). Elelyso ${ }^{\mathrm{TM}}$ has comparable enzymatic activity and uptake in macrophages and is structurally homologous to Cerezyme ${ }^{\mathbb{B}}$ (imiglucerase), manufactured in $\mathrm{CHO}$ cells by Genzyme $[57,238]$. Elelyso ${ }^{\mathrm{TM}}$, however, is $\sim 25 \%$ less expensive than Cerezyme ${ }^{\circledR}$ because the plant cell-synthesized enzyme does not require further modification of its $\mathrm{N}$-glycans for clinical use after bioproduction (terminal mannose residues are already exposed) [57]. Protalix's development pipeline for therapeutic enzymes includes PRX-102, a pegylated version of a recombinant human $\alpha$-galactosidase enzyme for the treatment of Fabry disease; PRX-110, a chemically modified DNase I for the treatment of cystic fibrosis; and PRX-112, an orally delivered glucocerebrosidase enzyme for treatment of Gaucher's disease. To date, 
Protalix has successfully completed a Phase I clinical trial of PRX-112 in Gaucher's patients. In June 2016, the company initiated its Phase III clinical trial of PRX-102.

There are also three moss-derived enzyme products targeted for enzyme replacement therapies: $\alpha$-galactosidase for Fabry disease, $\beta$-glucocerebrosidase for Gaucher's disease, and factor H for atypical hemolytic uremic syndrome are under Phase I and/or preclinical development by the German biotech company, Greenovation (www.greenovation.com/). With the cGMP-compliant manufacturing process well established in Greenovation, the first moss-expressed biopharmaceutical is expected to come to market in the near future.

\subsubsection{Other Therapeutics}

Other plant-made therapeutics such as human growth factor and cytokines are in clinical trials or are already on the market. For example, using barley grain as a production host (Orfeus ${ }^{\mathrm{TM}}$ platform), ORF Genetics produced high-grade, animal-free, and endotoxin-free human growth factors and cytokines (ISOkine ${ }^{\mathrm{TM}}$ growth factors and cytokines) targeted for stem cell research (www.orfgenetics.com/ ). About twenty ISOkine ${ }^{\mathrm{TM}}$ products, such as IL-3, GM-CSF, EGF, TNF, SCF, etc., are also on the market (http://orfgenetics.com/ISOkine/ProductList/). Commercialization of several moss-made human growth factors, including FGF7/KGF (keratinocyte growth factor), EGF, and HGF (hepatocyte growth factor) intended for mammalian cell culture, has also been achieved by Greenovation [77]. FGF7/ $\mathrm{KGF}$ is the first commercially available moss-made human protein. In addition, PRX-106, an oral formulation of anti-TNF $\alpha$ for treatment of immune and inflammatory-mediated disorders, is through Phase I clinical trial by Protalix, showing that the drug was safe and well tolerated and had gut biological activity and induction of regulatory $\mathrm{T}$ cells (www.protalix.com).

\subsection{Plant-Produced Biopolymers}

Compared to industrial enzymes and therapeutic proteins, commercial development of plant-made protein biopolymers lags. The major biopolymer products expressed in transgenic plants include collagens [239], spider silk proteins [22, 182], elastinlike polypeptides [15], and plant gum [240], which are promising biomaterials for regenerative medicine and tissue engineering as well as for the food industry [241].

\section{Conclusions}

Large-scale production and commercialization, especially of therapeutic proteins using plant production platforms, has passed proof of concept. While there are always challenges for each product and downstream process efficiency can certainly be improved, the technology for producing recombinant proteins in plants is past its infancy. More work is still needed to realize the full potential for plant-made industrial proteins and enzymes. Although not all industrial sectors have equally 
progressed, the list of successfully commercialized plant-produced recombinant proteins is rapidly growing, suggesting a bright future for the biotechnology industry.

\section{References}

1. Obembe OO, Popoola JO, Leelavathi S, Reddy SV (2011) Advances in plant molecular farming. Biotechnol Adv 29:210-222

2. Paul M, Ma JK (2011) Plant-made pharmaceuticals: leading products and production platforms. Biotechnol Appl Biochem 58:58-67

3. Sharma AK, Sharma MK (2009) Plants as bioreactors: Recent developments and emerging opportunities. Biotechnol Adv 27:811-832

4. Pogue GP, Vojdani F, Palmer KE, Hiatt E, Hume S, Phelps J, Long L, Bohorova N, Kim D, Pauly M (2010) Production of pharmaceutical-grade recombinant aprotinin and a monoclonal antibody product using plant-based transient expression systems. Plant Biotechnol J 8:638-654

5. Xu J, Ge X, Dolan MC (2011) Towards high-yield production of pharmaceutical proteins with plant cell suspension cultures. Biotechnol Adv 29:278-299

6. Boothe J, Nykiforuk C, Shen Y, Zaplachinski S, Szarka S, Kuhlman P, Murray E, Morck D, Moloney MM (2010) Seed-based expression systems for plant molecular farming. Plant Biotechnol J 8:588-606

7. Hood EE (2002) From green plants to industrial enzymes. Enzyme Microb Technol 30:279-283

8. Shih SMH, Doran PM (2009) Foreign protein production using plant cell and organ cultures: advantages and limitations. Biotechnol Adv 27:1036-1042

9. Tschofen M, Knopp D, Hood E, Stöger E (2016) Plant molecular farming: much more than medicines. Annu Rev Anal Chem 9:271-294

10. Boyhan D, Daniell H (2011) Low-cost production of proinsulin in tobacco and lettuce chloroplasts for injectable or oral delivery of functional insulin and C-peptide. Plant Biotechnol J 9:585-598

11. Shil PK, Kwon K-C, Zhu P, Verma A, Daniell H, Li Q (2014) Oral delivery of ACE2/Ang(1-7) bioencapsulated in plant cells protects against experimental uveitis and autoimmune uveoretinitis. Mol Ther 22:2069-2082

12. Shaaltiel Y, Gingis-Velitski S, Tzaban S, Fiks N, Tekoah Y, Aviezer D (2015) Plant-based oral delivery of $\beta$-glucocerebrosidase as an enzyme replacement therapy for Gaucher's disease. Plant Biotechnol J 13:1033-1040

13. Fischer R, Schillberg S, Hellwig S, Twyman RM, Drossard J (2012) GMP issues for recombinant plant-derived pharmaceutical proteins. Biotechnol Adv 30:434-439

14. Scheller J, Conrad U (2005) Plant-based material, protein and biodegradable plastic. Curr Opin Plant Biol 8:188-196

15. Conley AJ, Joensuu JJ, Menassa R, Brandle JE (2009) Induction of protein body formation in plant leaves by elastin-like polypeptide fusions. BMC Biol 7:48

16. Conley AJ, Joensuu JJ, Richman A, Menassa R (2011) Protein body-inducing fusions for highlevel production and purification of recombinant proteins in plants. Plant Biotechnol $\mathrm{J}$ 9:419-433

17. Patel J, Zhu H, Menassa R, Gyenis L, Richman A, Brandle J (2007) Elastin-like polypeptide fusions enhance the accumulation of recombinant proteins in tobacco leaves. Transgenic Res 16:239-249

18. Shoseyov O, Posen Y, Grynspan F (2013) Human recombinant type I collagen produced in plants. Tissue Eng Part A 19:1527-1533 
19. Shilo S, Roth S, Amzel T, Harel-Adar T, Tamir E, Grynspan F, Shoseyov O (2013) Cutaneous wound healing after treatment with plant-derived human recombinant collagen flowable gel. Tissue Eng Part A 19:1519-1526

20. Willard JJ, Drexler JW, Das A, Roy S, Shilo S, Shoseyov O, Powell HM (2013) Plant-derived human collagen scaffolds for skin tissue engineering. Tissue Eng Part A 19:1507-1518

21. Hinman MB, Jones JA, Lewis RV (2000) Synthetic spider silk: a modular fiber. Trends Biotechnol 18:374-379

22. Scheller J, Guhrs KH, Grosse F, Conrad U (2001) Production of spider silk proteins in tobacco and potato. Nat Biotechnol 19:573-577

23. Eisoldt L, Smith A, Scheibel T (2011) Decoding the secrets of spider silk. Mater Today 14:80-86

24. Yang J, Barr LA, Fahnestock SR, Liu Z-B (2005) High yield recombinant silk-like protein production in transgenic plants through protein targeting. Transgenic Res 14:313-324

25. Rising A, Johansson J (2015) Toward spinning artificial spider silk. Nat Chem Biol 11:309-315

26. Horn ME, Woodard SL, Howard JA (2004) Plant molecular farming: systems and products. Plant Cell Rep 22:711-720

27. Basaran P, Rodriguez-Cerezo E (2008) Plant molecular farming: opportunities and challenges. Crit Rev Biotechnol 28:153-172

28. Christou P, Stoger E, Twyman RM (2008) Monocot expression systems for molecular farming. In: Protein science encyclopedia. Wiley-Blackwell, Weinheim, pp55-67

29. Davies HM (2010) Review article: commercialization of whole-plant systems for biomanufacturing of protein products: evolution and prospects. Plant Biotechnol J 8:845-861

30. De Muynck B, Navarre C, Boutry M (2010) Production of antibodies in plants: status after twenty years. Plant Biotechnol J 8:529-563

31. Yusibov V, Kushnir N, Streatfield SJ (2016) Antibody production in plants and green algae. Annu Rev Plant Biol 67:669-701

32. Vunsh R, Li J, Hanania U, Edelman M, Flaishman M, Perl A, Wisniewski JP, Freyssinet G (2007) High expression of transgene protein in Spirodela. Plant Cell Rep 26:1511-1519

33. McDonald KA, Hong LM, Trombly DM, Xie Q, Jackman AP (2005) Production of human alpha-1-antitrypsin from transgenic rice cell culture in a membrane bioreactor. Biotechnol Prog 21:728-734

34. Doran PM (2000) Foreign protein production in plant tissue cultures. Curr Opin Biotechnol 11:199-204

35. Gomord V, Fitchette AC, Menu-Bouaouiche L, Saint-Jore-Dupas C, Plasson C, Michaud D, Faye L (2010) Plant-specific glycosylation patterns in the context of therapeutic protein production. Plant Biotechnol J 8:564-587

36. Gomord V, Chamberlain P, Jefferis R, Faye L (2005) Biopharmaceutical production in plants: problems, solutions and opportunities. Trends Biotechnol 23:559-565

37. Paccalet T, Bardor M, Rihouey C, Delmas F, Chevalier C, D'Aoust MA, Faye L, Vézina L, Gomord V, Lerouge P (2007) Engineering of a sialic acid synthesis pathway in transgenic plants by expression of bacterial Neu5Ac-synthesizing enzymes. Plant Biotechnol J 5:16-25

38. Bakker H, Rouwendal GJA, Karnoup AS, Florack DEA, Stoopen GM, Helsper JPFG, van Ree R, van Die I, Bosch D (2006) An antibody produced in tobacco expressing a hybrid $\beta-1$, 4-galactosyltransferase is essentially devoid of plant carbohydrate epitopes. Proc Natl Acad Sci 103:7577-7582

39. Schähs M, Strasser R, Stadlmann J, Kunert R, Rademacher T, Steinkellner H (2007) Production of a monoclonal antibody in plants with a humanized N-glycosylation pattern. Plant Biotechnol J 5:657-663

40. Strasser R, Stadlmann J, Schähs M, Stiegler G, Quendler H, Mach L, Glössl J, Weterings K, Pabst M, Steinkellner H (2008) Generation of glyco-engineered Nicotiana benthamiana for the production of monoclonal antibodies with a homogeneous human-like $\mathrm{N}$-glycan structure. Plant Biotechnol J 6:392-402 
41. Vézina LP, Faye L, Lerouge P, D’Aoust MA, Marquet-Blouin E, Burel C, Lavoie PO, Bardor M, Gomord V (2009) Transient co-expression for fast and high-yield production of antibodies with human-like N-glycans in plants. Plant Biotechnol J 7:442-455

42. Aviezer D, Almon-Brill E, Shaaltiel Y, Galili G, Chertkoff R, Hashmueli S, Galun E, Zimran A (2009) Novel enzyme replacement therapy for Gaucher disease: ongoing phase III clinical trial with recombinant human glucocerebrosidase expressed in plant cells. Mol Genet Metab 96: S13-S14

43. Aviezer D, Almon-Brill E, Shaaltiel Y, Chertkoff R, Hashmueli S, Zimran A (2010) Novel enzyme replacement therapy for Gaucher disease: phase III pivotal clinical trial with plant cell expressed recombinant glucocerebrosidase (prGCD) - taliglucerase alpha. Mol Genet Metab 99:S9-S10

44. Shaaltiel Y, Tekoah Y (2016) Plant specific N-glycans do not have proven adverse effects in humans. Nat Biotechnol 34:706-708

45. Faye L, Gomord V (2010) Success stories in molecular farming - a brief overview. Plant Biotechnol J 8:525-528

46. Cramer CL, Dolan MC, Reidy MJ (2008) Methods of delivery of molecules to cells using a ricin subunit and compositions relating to same. In: Google Patents

47. Phoolcharoen W, Dye JM, Kilbourne J, Piensook K, Pratt WD, Arntzen CJ, Chen Q, Mason HS, Herbst-Kralovetz MM (2011) A nonreplicating subunit vaccine protects mice against lethal Ebola virus challenge. Proc Natl Acad Sci 108:20695-20700

48. Xu J, Tan L, Goodrum KJ, Kieliszewski MJ (2007) High-yields and extended serum half-life of human interferon alpha $2 \mathrm{~b}$ expressed in tobacco cells as Arabinogalactan-protein fusions. Biotechnol Bioeng 97:997-1008

49. Xu J, Okada S, Tan L, Goodrum KJ, Kopchick JJ, Kieliszewski MJ (2010) Human growth hormone expressed in tobacco cells as an arabinogalactan-protein fusion glycoprotein has a prolonged serum life. Transgenic Res 19:849-867

50. Xu J, Zhang N (2014) On the way to commercializing plant cell culture platform for biopharmaceuticals: present status and prospect. Pharm Bioprocess 2:499-518

51. Schillberg S, Raven N, Fischer R, Twyman RM, Schiermeyer A (2013) Molecular farming of pharmaceutical proteins using plant suspension cell and tissue cultures. Curr Pharm Des 19:5531-5542

52. Holland T, Sack M, Rademacher T, Schmale K, Altmann F, Stadlmann J, Fischer R, Hellwig S (2010) Optimal nitrogen supply as a key to increased and sustained production of a monoclonal full-size antibody in BY-2 suspension culture. Biotechnol Bioeng 107:278-289

53. Vasilev N, Gromping U, Lipperts A, Raven N, Fischer R, Schillberg S (2013) Optimization of BY-2 cell suspension culture medium for the production of a human antibody using a combination of fractional factorial designs and the response surface method. Plant Biotechnol J 11:867-874

54. Yano A, Maeda F, Takekoshi M (2004) Transgenic tobacco cells producing the human monoclonal antibody to hepatitis B virus surface antigen. J Med Virol 73:208-215

55. Kim TG, Baek MY, Lee EK, Kwon TH, Yang MS (2008) Expression of human growth hormone in transgenic rice cell suspension culture. Plant Cell Rep 27:885-891

56. Shin YJ, Hong SY, Kwon TH, Jang YS, Yang MS (2003) High level of expression of recombinant human granulocyte-macrophage colony stimulating factor in transgenic rice cell suspension culture. Biotechnol Bioeng 82:778-783

57. Shaaltiel Y, Bartfeld D, Hashmueli S, Baum G, Brill-Almon E, Galili G, Dym O, BoldinAdamsky SA, Silman I, Sussman JL, Futerman AH, Aviezer D (2007) Production of glucocerebrosidase with terminal mannose glycans for enzyme replacement therapy of Gaucher's disease using a plant cell system. Plant Biotechnol J 5:579-590

58. Kizhner T, Azulay Y, Hainrichson M, Tekoah Y, Arvatz G, Shulman A, Ruderfer I, Aviezer D, Shaaltiel Y (2015) Characterization of a chemically modified plant cell culture expressed human alpha-Galactosidase-A enzyme for treatment of Fabry disease. Mol Genet Metab 114:259-267 
59. Shin YJ, Lee NJ, Kim J, An XH, Yang MS, Kwon TH (2010) High-level production of bioactive heterodimeric protein human interleukin-12 in rice. Enzyme Microb Technol 46:347-351

60. Liu YK, Li YT, Lu CF, Huang LF (2015) Enhancement of recombinant human serum albumin in transgenic rice cell culture system by cultivation strategy. N Biotechnol 32:328-334

61. Zhang N, Gonzalez M, Savary B, Xu J (2016) High-yield secretion of recombinant proteins expressed in tobacco cell culture with a designer glycopeptide tag: process development. Biotechnol J 11:497-506

62. Hakkinen ST, Raven N, Henquet M, Laukkanen ML, Anderlei T, Pitkanen JP, Twyman RM, Bosch D, Oksman-Caldentey KM, Schillberg S, Ritala A (2014) Molecular farming in tobacco hairy roots by triggering the secretion of a pharmaceutical antibody. Biotechnol Bioeng 111:336-346

63. Lonoce C, Salem R, Marusic C, Jutras PV, Scaloni A, Salzano AM, Lucretti S, Steinkellner H, Benvenuto E, Donini M (2016) Production of a tumour-targeting antibody with a humancompatible glycosylation profile in $\mathrm{N}$. benthamiana hairy root cultures. Biotechnol $\mathrm{J}$ 11:1209-1220

64. Rukavtsova EB, Abramikhina TV, Shulga NY, Bykov VA, Bur'yanov YI (2007) Tissue specific expression of hepatitis B virus surface antigen in transgenic plant cells and tissue culture. Russ J Plant Physiol 54:770-775

65. Martinez C, Petruccelli S, Giulietti AMA, Alvarez MA (2005) Expression of the antibody 14D9 in Nicotiana tabacum hairy roots. Electron J Biotechnol 8:170-176

66. Parsons J, Wirth S, Dominguez M, Bravo-Almonacid F, Giulietti AM, Rodriguez Talou J (2010) Production of human epidermal growth factor (hEGF) by in vitro cultures of nicotiana tabacum: effect of tissue differentiation and sodium nitroprusside addition. Int $\mathrm{J}$ Biotechnol Biochem 6:131-138

67. Pham NB, Schafer H, Wink M (2012) Production and secretion of recombinant thaumatin in tobacco hairy root cultures. Biotechnol J 7:537-545

68. Huet Y, Ekouna JP, Caron A, Mezreb K, Boitel-Conti M, Guerineau F (2014) Production and secretion of a heterologous protein by turnip hairy roots with superiority over tobacco hairy roots. Biotechnol Lett 36:181-190

69. Kim SR, Sim JS, Ajjappala H, Kim YH, Hahn BS (2012) Expression and large-scale production of the biochemically active human tissue-plasminogen activator in hairy roots of Oriental melon (Cucumis melo). J Biosci Bioeng 113:106-111

70. Nabiabad HS, Piri K, Amini M (2016) Expression of active chimeric-tissue plasminogen activator in tobacco hairy roots, Identification of a DNA aptamer and purification by aptamer functionalized-MWCNTs chromatography. Protein Expr Purif. doi:10.1016/j.pep.2016.02.004

71. Baur A, Reski R, Gorr G (2005) Enhanced recovery of a secreted recombinant human growth factor using stabilizing additives and by co-expression of human serum albumin in the moss Physcomitrella patens. Plant Biotechnol J 3:331-340

72. Koprivova A, Stemmer C, Altmann F, Hoffmann A, Kopriva S, Gorr G, Reski R, Decker EL (2004) Targeted knockouts of Physcomitrella lacking plant-specific immunogenic N-glycans. Plant Biotechnol J 2:517-523

73. Weise A, Altmann F, Rodriguez-Franco M, Sjoberg ER, Baumer W, Launhardt H, Kietzmann M, Gorr G (2007) High-level expression of secreted complex glycosylated recombinant human erythropoietin in the Physcomitrella Delta-fuc-t Delta-xyl-t mutant. Plant Biotechnol J 5:389-401

74. Parsons J, Altmann F, Arrenberg CK, Koprivova A, Beike AK, Stemmer C, Gorr G, Reski R, Decker EL (2012) Moss-based production of asialo-erythropoietin devoid of Lewis A and other plant-typical carbohydrate determinants. Plant Biotechnol J 10:851-861

75. Buttner-Mainik A, Parsons J, Jerome H, Hartmann A, Lamer S, Schaaf A, Schlosser A, Zipfel PF, Reski R, Decker EL (2011) Production of biologically active recombinant human factor $\mathrm{H}$ in Physcomitrella. Plant Biotechnol J 9:373-383 
76. Orellana-Escobedo L, Rosales-Mendoza S, Romero-Maldonado A, Parsons J, Decker EL, Monreal-Escalante E, Moreno-Fierros L, Reski R (2015) An Env-derived multi-epitope HIV chimeric protein produced in the moss Physcomitrella patens is immunogenic in mice. Plant Cell Rep 34:425-433

77. Niederkrüger H, Dabrowska-Schlepp P, Schaaf A (2014) Suspension culture of plant cells under phototrophic conditions. In: Meyer H-P, Schmidhalter DR (eds) Industrial scale suspension culture of living cells. Wiley-VCH Verlag $\mathrm{GmbH} \&$ Co. KGaA, Weinheim, pp 259-292

78. Sijmons PC, Dekker BM, Schrammeijer B, Verwoerd TC, van den Elzen PJ, Hoekema A (1990) Production of correctly processed human serum albumin in transgenic plants. Biotechnology (N Y) 8:217-221

79. Santos RB, Abranches R, Fischer R, Sack M, Holland T (2016) Putting the spotlight back on plant suspension cultures. Front Plant Sci 7:297

80. Huang TK, McDonald KA (2009) Bioreactor engineering for recombinant protein production in plant cell suspension cultures. Biochem Eng J 45:168-184

81. Hellwig S, Drossard J, Twyman RM, Fischer R (2004) Plant cell cultures for the production of recombinant proteins. Nat Biotechnol 22:1415-1422

82. Ozawa K, Takaiwa F (2010) Highly efficient Agrobacterium-mediated transformation of suspension-cultured cell clusters of rice (Oryza sativa L.). Plant Sci 179:333-337

83. Trexler MM, McDonald KA, Jackman AP (2005) A cyclical semicontinuous process for production of human alpha 1-antitrypsin using metabolically induced plant cell suspension cultures. Biotechnol Prog 21:321-328

84. Fischer R, Schillberg S, Buyel JF, Twyman RM (2013) Commercial aspects of pharmaceutical protein production in plants. Curr Pharm Des 19:5471-5477

85. Xu J, Dolan MC, Medrano G, Cramer CL, Weathers PJ (2012) Green factory: plants as bioproduction platforms for recombinant proteins. Biotechnol Adv 30:1171-1184

86. Havenith H, Raven N, Di Fiore S, Fischer R, Schillberg S (2014) Image-based analysis of cellspecific productivity for plant cell suspension cultures. Plant Cell Tiss Org Cult 117:393-399

87. James E, Lee JM (2006) Loss and recovery of protein productivity in genetically modified plant cell lines. Plant Cell Rep 25:723-727

88. Shanks JV, Morgan J (1999) Plant 'hairy root' culture. Curr Opin Biotechnol 10:151-155

89. Guillon S, Tremouillaux-Guiller J, Pati PK, Rideau M, Gantet P (2006) Harnessing the potential of hairy roots: dawn of a new era. Trends Biotechnol 24:403-409

90. Georgiev MI, Agostini E, Ludwig-Muller J, Xu J (2012) Genetically transformed roots: from plant disease to biotechnological resource. Trends Biotechnol 30:528-537

91. Wongsamuth R, Doran PM (1997) Production of monoclonal antibodies by tobacco hairy roots. Biotechnol Bioeng 54:401-415

92. Kowalczyk T, Lucka M, Szemraj J, Sakowicz T (2016) Hairy roots culture as a source of valuable biopharmaceuticals. Postepy Hig Med Dosw (Online) 70:1-9

93. Woods RR, Geyer BC, Mor TS (2008) Hairy-root organ cultures for the production of human acetylcholinesterase. BMC Biotechnol 8:95

94. Gaume A, Komarnytsky S, Borisjuk N, Raskin I (2003) Rhizosecretion of recombinant proteins from plant hairy roots. Plant Cell Rep 21:1188-1193

95. Hood EE, Cramer CL, Medrano G, Xu J (2012) Protein targeting: strategic planning for optimizing protein products through plant biotechnology. In: Altman A, Hasagawa PM (eds) Plant biotechnology and agriculture: prospects for the 21 st century. Elsevier, Amsterdam, pp $35-54$

96. Nopo L, Woffenden BJ, Reed DG, Buswell S, Zhang C, Medina-Bolivar F (2012) Superpromoter:TEV, a powerful gene expression system for tobacco hairy roots. Methods Mol Biol 824:501-526

97. Peebles CAM, Gibson SI, Shanks JV, San KY (2007) Long-term maintenance of a transgenic Catharanthus roseus hairy root line. Biotechnol Prog 23:1517-1518 
98. Ono NN, Tian L (2011) The multiplicity of hairy root cultures: prolific possibilities. Plant Sci 180:439-446

99. Parsons J, Altmann F, Graf M, Stadlmann J, Reski R, Decker EL (2013) A gene responsible for prolyl-hydroxylation of moss-produced recombinant human erythropoietin. Sci Rep 3:3019

100. von Stackelberg M, Rensing SA, Reski R (2006) Identification of genic moss SSR markers and a comparative analysis of twenty-four algal and plant gene indices reveal species-specific rather than group-specific characteristics of microsatellites. BMC Plant Biol 6:9

101. Schuster M, Jost W, Mudde GC, Wiederkum S, Schwager C, Janzek E, Altmann F, Stadlmann J, Stemmer C, Gorr G (2007) In vivo glyco-engineered antibody with improved lytic potential produced by an innovative non-mammalian expression system. Biotechnol $\mathrm{J}$ 2:700-708

102. Kircheis R, Halanek N, Koller I, Jost W, Schuster M, Gorr G, Hajszan K, Nechansky A (2012) Correlation of ADCC activity with cytokine release induced by the stably expressed, glycoengineered humanized Lewis Y-specific monoclonal antibody MB314. MAbs 4:532-541

103. Reski R, Parsons J, Decker EL (2015) Moss-made pharmaceuticals: from bench to bedside. Plant Biotechnol J 13:1191-1198

104. Huether CM, Lienhart O, Baur A, Stemmer C, Gorr G, Reski R, Decker EL (2005) Glycoengineering of moss lacking plant-specific sugar residues. Plant Biol (Stuttg) 7:292-299

105. Decker EL, Reski R (2012) Glycoprotein production in moss bioreactors. Plant Cell Rep 31:453-460

106. Decker EL, Parsons J, Reski R (2014) Glyco-engineering for biopharmaceutical production in moss bioreactors. Front Plant Sci 5:346

107. Weathers PJ, Towler MJ, Xu J (2010) Bench to batch: advances in plant cell culture for producing useful products. Appl Microbiol Biotechnol 85:1339-1351

108. Huang T-K, McDonald KA (2012) Bioreactor systems for in vitro production of foreign proteins using plant cell cultures. Biotechnol Adv 30:398-409

109. Georgiev MI, Eibl R, Zhong J-J (2013) Hosting the plant cells in vitro: recent trends in bioreactors. Appl Microbiol Biotechnol 97:3787-3800

110. Nohynek L, Bailey M, Tähtiharju J, Seppänen-Laakso T, Rischer H, Oksman-Caldentey KM, Puupponen-Pimiä R (2014) Cloudberry (Rubus chamaemorus) cell culture with bioactive substances: establishment and mass propagation for industrial use. Eng Life Sci 14:667-675

111. Reuter LJ, Bailey MJ, Joensuu JJ, Ritala A (2014) Scale-up of hydrophobin-assisted recombinant protein production in tobacco BY-2 suspension cells. Plant Biotechnol J 12:402-410

112. Hsiao TY, Bacani FT, Carvalho EB, Curtis WR (1999) Development of a low capital investment reactor system: application for plant cell suspension culture. Biotechnol Prog $15: 114-122$

113. Raven N, Rasche S, Kuehn C, Anderlei T, Klockner W, Schuster F, Henquet M, Bosch D, Buchs J, Fischer R, Schillberg S (2015) Scaled-up manufacturing of recombinant antibodies produced by plant cells in a 200-L orbitally-shaken disposable bioreactor. Biotechnol Bioeng 112:308-321

114. Eibl R, Kaiser S, Lombriser R, Eibl D (2010) Disposable bioreactors: the current state-of-theart and recommended applications in biotechnology. Appl Microbiol Biotechnol 86:41-49

115. Shaaltiel Y, Kirshner Y, Shtainiz A, Naos Y, Shneor Y (2008) Large scale disposable bioreactor. In: Google Patents

116. Tekoah Y, Shulman A, Kizhner T, Ruderfer I, Fux L, Nataf Y, Bartfeld D, Ariel T, GingisVelitski S, Hanania U, Shaaltiel Y (2015) Large-scale production of pharmaceutical proteins in plant cell culture-the protalix experience. Plant Biotechnol J 13:1199-1208

117. Firsov A, Tarasenko I, Mitiouchkina T, Ismailova N, Shaloiko L, Vainstein A, Dolgov S (2015) High-yield expression of M2e peptide of avian influenza virus H5N1 in transgenic duckweed plants. Mol Biotechnol 57:653-661

118. Stomp AM (2005) The duckweeds: a valuable plant for biomanufacturing. Biotechnol Annu Rev 11:69-99 
119. Rival S, Wisniewski JP, Langlais A, Kaplan H, Freyssinet G, Vancanneyt G, Vunsh R, Perl A, Edelman M (2008) Spirodela (duckweed) as an alternative production system for pharmaceuticals: a case study, aprotinin. Transgenic Res 17:503-513

120. Popov SV, Golovchenko VV, Ovodova RG, Smirnov VV, Khramova DS, Popova GY, Ovodov YS (2006) Characterisation of the oral adjuvant effect of lemnan, a pectic polysaccharide of Lemna minor L. Vaccine 24:5413-5419

121. Yamamoto YT, Rajbhandari N, Lin X, Bergmann BA, Nishimura Y, Stomp AM (2001) Genetic transformation of duckweed Lemna gibba and Lemna minor. In Vitro Cell Dev Biol Plant 37:349-353

122. Sun Y, Cheng JJ, Himmel ME, Skory CD, Adney WS, Thomas SR, Tisserat B, Nishimura Y, Yamamoto YT (2007) Expression and characterization of Acidothermus cellulolyticus E1 endoglucanase in transgenic duckweed Lemna minor 8627. Bioresour Technol 98:2866-2872

123. Cox KM, Sterling JD, Regan JT, Gasdaska JR, Frantz KK, Peele CG, Black A, Passmore D, Moldovan-Loomis C, Srinivasan M, Cuison S, Cardarelli PM, Dickey LF (2006) Glycan optimization of a human monoclonal antibody in the aquatic plant Lemna minor. Nat Biotechnol 24:1591-1597

124. Spencer D, Dickey LF, Gasdaska JR, Wang X, Cox KM, Peele CG (2010) Expression of plasminogen and microplasminogen in duck weed. United States Patent No 7659445

125. De Leede LG, Humphries JE, Bechet AC, Van Hoogdalem EJ, Verrijk R, Spencer DG (2008) Novel controlled-release Lemna-derived IFN-alpha2b (Locteron): pharmacokinetics, pharmacodynamics, and tolerability in a phase I clinical trial. J Interferon Cytokine Res 28:113-122

126. Guo X, Bublot M, Pritchard N, Dickey L, Thomas C, Swayne DE (2009) Lemna (duckweed) expressed hemagglutinin from avian influenza $\mathrm{H} 5 \mathrm{~N} 1$ protects chickens against $\mathrm{H} 5 \mathrm{~N} 1$ high pathogenicity avian influenza virus challenge In: Abstracts of the 7th international symposium on avian influenza 2009. Athens, $\mathrm{p} 62$

127. Bertran K, Thomas C, Guo X, Bublot M, Pritchard N, Regan JT, Cox KM, Gasdaska JR, Dickey LF, Kapczynski DR, Swayne DE (2015) Expression of H5 hemagglutinin vaccine antigen in common duckweed (Lemna minor) protects against H5N1 high pathogenicity avian influenza virus challenge in immunized chickens. Vaccine 33:3456-3462

128. Potvin G, Zhang ZS (2010) Strategies for high-level recombinant protein expression in transgenic microalgae: a review. Biotechnol Adv 28:910-918

129. Specht E, Miyake-Stoner S, Mayfield S (2010) Micro-algae come of age as a platform for recombinant protein production. Biotechnol Lett 32:1373-1383

130. Franklin SE, Mayfield SP (2005) Recent developments in the production of human therapeutic proteins in eukaryotic algae. Expert Opin Biol Ther 5:225-235

131. Barrera DJ, Mayfield SP (2013) High-value recombinant protein production in microalgae. In: Richmond A, Hu Q (eds) Handbook of microalgal culture: applied phycology and biotechnology, 2nd edn. Blackwell Publishing Ltd., Chichester

132. Yao J, Weng Y, Dickey A, Wang KY (2015) Plants as factories for human pharmaceuticals: applications and challenges. Int J Mol Sci 16:28549-28565

133. Dance A (2010) From pond scum to pharmacy shelf. Nat Med 16:146-149

134. Tran M, Zhou B, Pettersson PL, Gonzalez MJ, Mayfield SP (2009) Synthesis and assembly of a full-length human monoclonal antibody in algal chloroplasts. Biotechnol Bioeng 104:663-673

135. Rosenberg JN, Oyler GA, Wilkinson L, Betenbaugh MJ (2008) A green light for engineered algae: redirecting metabolism to fuel a biotechnology revolution. Curr Opin Biotechnol $19: 430-436$

136. Rasala BA, Muto M, Lee PA, Jager M, Cardoso RM, Behnke CA, Kirk P, Hokanson CA, Crea R, Mendez M, Mayfield SP (2010) Production of therapeutic proteins in algae, analysis of expression of seven human proteins in the chloroplast of Chlamydomonas reinhardtii. Plant Biotechnol J 8:719-733 
137. Mathieu-Rivet E, Kiefer-Meyer MC, Vanier G, Ovide C, Burel C, Lerouge P, Bardor M (2014) Protein N-glycosylation in eukaryotic microalgae and its impact on the production of nuclear expressed biopharmaceuticals. Front Plant Sci 5:359

138. Mayfield SP, Manuell AL, Chen S, Wu J, Tran M, Siefker D, Muto M, Marin-Navarro J (2007) Chlamydomonas reinhardtii chloroplasts as protein factories. Curr Opin Biotechnol $18: 126-133$

139. Xu L, Weathers PJ, Xiong XR, Liu CZ (2009) Microalgal bioreactors: challenges and opportunities. Eng Life Sci 9:178-189

140. Ganapathy M (2016) Plants as bioreactors-a review. Adv Tech Biol Med 4:161

141. Hiatt A, Cafferkey R, Bowdish K (1989) Production of antibodies in transgenic plants. Nature 342:76-78

142. Tremblay R, Wang D, Jevnikar AM, Ma S (2010) Tobacco, a highly efficient green bioreactor for production of therapeutic proteins. Biotechnol Adv 28:214-221

143. Twyman RM, Stoger E, Schillberg S, Christou P, Fischer R (2003) Molecular farming in plants: host systems and expression technology. Trends Biotechnol 21:570-578

144. Ma JK, Hikmat BY, Wycoff K, Vine ND, Chargelegue D, Yu L, Hein MB, Lehner T (1998) Characterization of a recombinant plant monoclonal secretory antibody and preventive immunotherapy in humans. Nat Med 4:601-606

145. Fischer R, Stoger E, Schillberg S, Christou P, Twyman RM (2004) Plant-based production of biopharmaceuticals. Curr Opin Plant Biol 7:152-158

146. Hehle VK, Paul MJ, Roberts VA, van Dolleweerd CJ, Ma JK (2016) Site-targeted mutagenesis for stabilization of recombinant monoclonal antibody expressed in tobacco (Nicotiana tabacum) plants. FASEB J 30:1590-1598

147. Ma JK, Drossard J, Lewis D, Altmann F, Boyle J, Christou P, Cole T, Dale P, van Dolleweerd CJ, Isitt V, Katinger D, Lobedan M, Mertens H, Paul MJ, Rademacher T, Sack M, Hundleby PA, Stiegler G, Stoger E, Twyman RM, Vcelar B, Fischer R (2015) Regulatory approval and a first-in-human phase I clinical trial of a monoclonal antibody produced in transgenic tobacco plants. Plant Biotechnol J 13:1106-1120

148. Triguero A, Cabrera G, Rodriguez M, Soto J, Zamora Y, Perez M, Wormald MR, Cremata JA (2011) Differential N-glycosylation of a monoclonal antibody expressed in tobacco leaves with and without endoplasmic reticulum retention signal apparently induces similar in vivo stability in mice. Plant Biotechnol J 9:1120-1130

149. Pogrebnyak N, Golovkin M, Andrianov V, Spitsin S, Smirnov Y, Egolf R, Koprowski H (2005) Severe acute respiratory syndrome (SARS) S protein production in plants: development of recombinant vaccine. Proc Natl Acad Sci U S A 102:9062-9067

150. Turchinovich AA, Deineko EV, Filipenko ML, Khrapov EA, Zagorskaya AA, Filipenko EA, Sennikov SV, Kozlov VA, Shumnyi VK (2004) Transgenic tobacco plants producing human interleukin-18. Dokl Biochem Biophys 395:104-107

151. Zhang B, Yang YH, Lin YM, Rao Q, Zheng GG, Wu KF (2003) Expression and production of bioactive human interleukin-18 in transgenic tobacco plants. Biotechnol Lett 25:1629-1635

152. Harrison MD, Zhang Z, Shand K, Chong BF, Nichols J, Oeller P, O'Hara IM, Doherty WO, Dale JL (2014) The combination of plant-expressed cellobiohydrolase and low dosages of cellulases for the hydrolysis of sugar cane bagasse. Biotechnol Biofuels 7:131

153. Brunecky R, Selig MJ, Vinzant TB, Himmel ME, Lee D, Blaylock MJ, Decker SR (2011) In planta expression of A. cellulolyticus Cel5A endocellulase reduces cell wall recalcitrance in tobacco and maize. Biotechnol Biofuels 4:1

154. Fischer R, Vasilev N, Twyman RM, Schillberg S (2015) High-value products from plants: the challenges of process optimization. Curr Opin Biotechnol 32:156-162

155. Saberianfar R, Joensuu JJ, Conley AJ, Menassa R (2015) Protein body formation in leaves of Nicotiana benthamiana: a concentration-dependent mechanism influenced by the presence of fusion tags. Plant Biotechnol J 13:927-937

156. Benchabane M, Goulet C, Rivard D, Faye L, Gomord V, Michaud D (2008) Preventing unintended proteolysis in plant protein biofactories. Plant Biotechnol J 6:633-648 
157. Bock R (2014) Genetic engineering of the chloroplast: novel tools and new applications. Curr Opin Biotechnol 26:7-13

158. Waheed MT, Ismail H, Gottschamel J, Mirza B, Lossl AG (2015) Plastids: the green frontiers for vaccine production. Front Plant Sci 6:1005

159. Ruhlman T, Verma D, Samson N, Daniell H (2010) The role of heterologous chloroplast sequence elements in transgene integration and expression. Plant Physiol 152:2088-2104

160. Kohli N, Westerveld DR, Ayache AC, Verma A, Shil P, Prasad T, Zhu P, Chan SL, Li Q, Daniell H (2014) Oral delivery of bioencapsulated proteins across blood-brain and bloodretinal barriers. Mol Ther J Am Soc Gene Ther 22:535-546

161. Jin S, Daniell H (2015) The engineered chloroplast genome just got smarter. Trends Plant Sci 20:622-640

162. Kwon KC, Verma D, Singh ND, Herzog R, Daniell H (2013) Oral delivery of human biopharmaceuticals, autoantigens and vaccine antigens bioencapsulated in plant cells. Adv Drug Deliv Rev 65:782-799

163. Egelkrout E, Rajan V, Howard JA (2012) Overproduction of recombinant proteins in plants. Plant Sci 184:83-101

164. Kwon KC, Daniell H (2016) Oral delivery of protein drugs bioencapsulated in plant cells. Mol Ther 24:1342-1350

165. Su J, Zhu L, Sherman A, Wang X, Lin S, Kamesh A, Norikane JH, Streatfield SJ, Herzog RW, Daniell H (2015) Low cost industrial production of coagulation factor IX bioencapsulated in lettuce cells for oral tolerance induction in hemophilia B. Biomaterials 70:84-93

166. Su J, Sherman A, Doerfler PA, Byrne BJ, Herzog RW, Daniell H (2015) Oral delivery of Acid Alpha Glucosidase epitopes expressed in plant chloroplasts suppresses antibody formation in treatment of Pompe mice. Plant Biotechnol J 13:1023-1032

167. Chan HT, Daniell H (2015) Plant-made oral vaccines against human infectious diseases-Are we there yet? Plant Biotechnol J 13:1056-1070

168. Kwon KC, Daniell H (2015) Low-cost oral delivery of protein drugs bioencapsulated in plant cells. Plant Biotechnol J 13:1017-1022

169. Juarez P, Virdi V, Depicker A, Orzaez D (2016) Biomanufacturing of protective antibodies and other therapeutics in edible plant tissues for oral applications. Plant Biotechnol J 14:1791-1799

170. Lau OS, Sun SS (2009) Plant seeds as bioreactors for recombinant protein production. Biotechnol Adv 27:1015-1022

171. Ma JK, Drake PM, Christou P (2003) The production of recombinant pharmaceutical proteins in plants. Nat Rev Genet 4:794-805

172. Stoger E, Sack M, Fischer R, Christou P (2002) Plantibodies: applications, advantages and bottlenecks. Curr Opin Biotechnol 13:161-166

173. Sabalza M, Vamvaka E, Christou P, Capell T (2013) Seeds as a production system for molecular pharming applications: status and prospects. Curr Pharm Des 19:5543-5552

174. Ramessar K, Capell T, Christou P (2008) Molecular pharming in cereal crops. Phytochem Rev 7:579-592

175. Stoger E, Ma JK, Fischer R, Christou P (2005) Sowing the seeds of success: pharmaceutical proteins from plants. Curr Opin Biotechnol 16:167-173

176. Rademacher T, Sack M, Arcalis E, Stadlmann J, Balzer S, Altmann F, Quendler H, Stiegler G, Kunert R, Fischer R, Stoger E (2008) Recombinant antibody 2G12 produced in maize endosperm efficiently neutralizes HIV-1 and contains predominantly single-GlcNAc N-glycans. Plant Biotechnol J 6:189-201

177. Van Droogenbroeck B, Cao J, Stadlmann J, Altmann F, Colanesi S, Hillmer S, Robinson DG, Van Lerberge E, Terryn N, Van Montagu M, Liang M, Depicker A, De Jaeger G (2007) Aberrant localization and underglycosylation of highly accumulating single-chain Fv-Fc antibodies in transgenic Arabidopsis seeds. Proc Natl Acad Sci U S A 104:1430-1435 
178. Sardana R, Dudani AK, Tackaberry E, Alli Z, Porter S, Rowlandson K, Ganz P, Altosaar I (2007) Biologically active human GM-CSF produced in the seeds of transgenic rice plants. Transgenic Res 16:713-721

179. Woodard SL, Mayor JM, Bailey MR, Barker DK, Love RT, Lane JR, Delaney DE, McComasWagner JM, Mallubhotla HD, Hood EE, Dangott LJ, Tichy SE, Howard JA (2003) Maize (Zea mays)-derived bovine trypsin: characterization of the first large-scale, commercial protein product from transgenic plants. Biotechnol Appl Biochem 38:123-130

180. Chen R, Xue G, Chen P, Yao B, Yang W, Ma Q, Fan Y, Zhao Z, Tarczynski MC, Shi J (2008) Transgenic maize plants expressing a fungal phytase gene. Transgenic Res 17:633-643

181. Hood EE, Love R, Lane J, Bray J, Clough R, Pappu K, Drees C, Hood KR, Yoon S, Ahmad A, Howard JA (2007) Subcellular targeting is a key condition for high-level accumulation of cellulase protein in transgenic maize seed. Plant Biotechnol J 5:709-719

182. Weichert N, Hauptmann V, Helmold C, Conrad U (2016) Seed-specific expression of spider silk protein multimers causes long-term stability. Front Plant Sci 7:6

183. Giddings G, Allison G, Brooks D, Carter A (2000) Transgenic plants as factories for biopharmaceuticals. Nat Biotechnol 18:1151-1155

184. Naqvi S, Ramessar K, Farre G, Sabalza M, Miralpeix B, Twyman RM, Capell T, Zhu C, Christou P (2011) High-value products from transgenic maize. Biotechnol Adv 29:40-53

185. Ramessar K, Rademacher T, Sack M, Stadlmann J, Platis D, Stiegler G, Labrou N, Altmann F, Ma J, Stoger E, Capell T, Christou P (2008) Cost-effective production of a vaginal protein microbicide to prevent HIV transmission. Proc Natl Acad Sci U S A 105:3727-3732

186. Nahampun HN, Bosworth B, Cunnick J, Mogler M, Wang K (2015) Expression of H3N2 nucleoprotein in maize seeds and immunogenicity in mice. Plant Cell Rep 34:969-980

187. Yang W, Zhang Y, Zhou X, Zhang W, Xu X, Chen R, Meng Q, Yuan J, Yang P, Yao B (2015) Production of a highly protease-resistant fungal alpha-galactosidase in transgenic maize seeds for simplified feed processing. PLoS One 10:e129294

188. Zhang D (2013) Plant seed-derived human transferrin: expression, characterization, and applications. Biotechnol 2:17

189. Magnusdottir A, Vidarsson H, Bjornsson JM, Orvar BL (2013) Barley grains for the production of endotoxin-free growth factors. Trends Biotechnol 31:572-580

190. McLean MD, Chen R, Yu D, Mah KZ, Teat J, Wang H, Zaplachinski S, Boothe J, Hall JC (2012) Purification of the therapeutic antibody trastuzumab from genetically modified plants using safflower Protein A-oleosin oilbody technology. Transgenic Res 21:1291-1301

191. Vargo KB, Parthasarathy R, Hammer DA (2012) Self-assembly of tunable protein suprastructures from recombinant oleosin. Proc Natl Acad Sci U S A 109:11657-11662

192. Vitale A, Pedrazzini E (2005) Recombinant pharmaceuticals from plants: the plant endomembrane system as bioreactor. Mol Interv 5:216-225

193. Schillberg S, Twyman RM, Fischer R (2005) Opportunities for recombinant antigen and antibody expression in transgenic plants-technology assessment. Vaccine 23:1764-1769

194. Fujiuchi N, Matoba N, Matsuda R (2016) Environment control to improve recombinant protein yields in plants based on agrobacterium-mediated transient gene expression. Front Bioeng Biotechnol 4:23

195. Krenek P, Samajova O, Luptovciak I, Doskocilova A, Komis G, Samaj J (2015) Transient plant transformation mediated by Agrobacterium tumefaciens: principles, methods and applications. Biotechnol Adv 33:1024-1042

196. Komarova TV, Baschieri S, Donini M, Marusic C, Benvenuto E, Dorokhov YL (2010) Transient expression systems for plant-derived biopharmaceuticals. Expert Rev Vaccines 9:859-876

197. Chen Q, Lai H (2015) Gene delivery into plant cells for recombinant protein production. BioMed Res Int. Article ID 932161

198. Leuzinger K, Dent M, Hurtado J, Stahnke J, Lai H, Zhou X, Chen Q (2013) Efficient agroinfiltration of plants for high-level transient expression of recombinant proteins. J Vis Exp 77:50521 
199. Fischer R, Vaquero-Martin C, Sack M, Drossard J, Emans N, Commandeur U (1999) Towards molecular farming in the future: transient protein expression in plants. Biotechnol Appl Biochem 30(Pt 2):113-116

200. Matoba N, Davis KR, Palmer KE (2011) Recombinant protein expression in Nicotiana. Methods Mol Biol 701:199-219

201. Marillonnet S, Giritch A, Gils M, Kandzia R, Klimyuk V, Gleba Y (2004) In planta engineering of viral RNA replicons: efficient assembly by recombination of DNA modules delivered by Agrobacterium. Proc Natl Acad Sci U S A 101:6852-6857

202. Gleba Y, Klimyuk V, Marillonnet S (2007) Viral vectors for the expression of proteins in plants. Curr Opin Biotechnol 18:134-141

203. Huang C, Xie Y, Zhou X (2009) Efficient virus-induced gene silencing in plants using a modified geminivirus DNA1 component. Plant Biotechnol J 7:254-265

204. Gleba Y, Klimyuk V, Marillonnet S (2005) Magnifection-a new platform for expressing recombinant vaccines in plants. Vaccine 23:2042-2048

205. Chen Q, Davis KR (2016) The potential of plants as a system for the development and production of human biologics. F1000Res 19:5

206. Holtz BR, Berquist BR, Bennett LD, Kommineni VJ, Munigunti RK, White EL, Wilkerson DC, Wong KY, Ly LH, Marcel S (2015) Commercial-scale biotherapeutics manufacturing facility for plant-made pharmaceuticals. Plant Biotechnol J 13:1180-1190

207. Olinger GG, Pettitt J, Kim D, Working C, Bohorov O, Bratcher B, Hiatt E, Hume SD, Johnson AK, Morton J, Pauly M, Whaley KJ, Lear CM, Biggins JE, Scully C, Hensley L, Zeitlin L (2012) Delayed treatment of Ebola virus infection with plant-derived monoclonal antibodies provides protection in rhesus macaques. Proc Natl Acad Sci U S A 109:18030-18035

208. Qiu X, Audet J, Wong G, Fernando L, Bello A, Pillet S, Alimonti JB, Kobinger GP (2013) Sustained protection against Ebola virus infection following treatment of infected nonhuman primates with ZMAb. Sci Rep 3:3365

209. Dicker M, Tschofen M, Maresch D, Konig J, Juarez P, Orzaez D, Altmann F, Steinkellner H, Strasser R (2016) Transient glyco-engineering to produce recombinant IgA1 with defined Nand O-glycans in plants. Front Plant Sci 7:18

210. Rosenberg Y, Sack M, Montefiori D, Forthal D, Mao L, Hernandez-Abanto S, Urban L, Landucci G, Fischer R, Jiang X (2013) Rapid high-level production of functional HIV broadly neutralizing monoclonal antibodies in transient plant expression systems. PLoS One 8:e58724

211. Redkiewicz P, Sirko A, Kamel KA, Gora-Sochacka A (2014) Plant expression systems for production of hemagglutinin as a vaccine against influenza virus. Acta Biochim Pol 61:551-560

212. D'Aoust MA, Lavoie PO, Couture MM, Trépanier S, Guay JM, Dargis M, Mongrand S, Landry N, Ward BJ, Vézina LP (2008) Influenza virus-like particles produced by transient expression in Nicotiana benthamiana induce a protective immune response against a lethal viral challenge in mice. Plant Biotechnol J 6:930-940

213. Boes A, Reimann A, Twyman RM, Fischer R, Schillberg S, Spiegel H (2016) A plant-based transient expression system for the rapid production of malaria vaccine candidates. Methods Mol Biol 1404:597-619

214. Spiegel H, Boes A, Voepel N, Beiss V, Edgue G, Rademacher T, Sack M, Schillberg S, Reimann A, Fischer R (2015) Application of a scalable plant transient gene expression platform for malaria vaccine development. Front Plant Sci 6:1169

215. Gomez E, Lucero MS, Chimeno Zoth S, Carballeda JM, Gravisaco MJ, Berinstein A (2013) Transient expression of VP2 in Nicotiana benthamiana and its use as a plant-based vaccine against infectious bursal disease virus. Vaccine 31:2623-2627

216. Acosta W, Ayala J, Dolan M, Cramer C (2015) RTB Lectin: a novel receptor-independent delivery system for lysosomal enzyme replacement therapies. Sci Rep 5

217. Marsian J, Lomonossoff GP (2016) Molecular pharming - VLPs made in plants. Curr Opin Biotechnol 37:201-206 
218. Stoger E, Fischer R, Moloney M, Ma JK (2014) Plant molecular pharming for the treatment of chronic and infectious diseases. Annu Rev Plant Biol 65:743-768

219. Paul MJ, Thangaraj H, Ma JK (2015) Commercialization of new biotechnology: a systematic review of 16 commercial case studies in a novel manufacturing sector. Plant Biotechnol J 13:1209-1220

220. Kim D-S, Song I, Kim J, Kim D-S, Ko K (2016) Plant recycling for molecular biofarming to produce recombinant anti-cancer mab. Front Plant Sci 7

221. Wilson SA, Roberts SC (2012) Recent advances towards development and commercialization of plant cell culture processes for the synthesis of biomolecules. Plant Biotechnol J 10:249-268

222. Howard JA, Hood EE (2014) Commercial plant-produced recombinant protein products: case studies. Springer, Heidelberg

223. Basaran P, Rodriguez-Cerezo E (2008) An assessment of emerging molecular farming activities based on patent analysis (2002 similar to 2006). Biotechnol Bioproc Eng 13:304-312

224. Witcher DR, Hood EE, Peterson D, Bailey M, Bond D, Kusnadi A, Evangelista R, Nikolov Z, Wooge C, Mehigh R, Kappel W, Register JC, Howard JA (1998) Commercial production of $\beta$-glucuronidase (GUS): a model system for the production of proteins in plants. Mol Breed 4:301-312

225. Hood EE, Devaiah SP, Fake G, Egelkrout E, Teoh KT, Requesens DV, Hayden C, Hood KR, Pappu KM, Carroll J, Howard JA (2011) Manipulating corn germplasm to increase recombinant protein accumulation. Plant Biotechnol J 10:20-30

226. Sticklen MB (2007) Production of ss-glucosidase, hemicellulase and ligninase in E1 and FLCcellulase-transgenic plants. US Patent Application 20070192900

227. Hirai H, Kashima Y, Hayashi K, Sugiura T, Yamagishi K, Kawagishi H, Nishida T (2008) Efficient expression of laccase gene from white-rot fungus Schizophyllum commune in a transgenic tobacco plant. FEMS Microbiol Lett 286:130-135

228. Waltz E (2011) Amylase corn sparks worries. Nat Biotechnol 29:294

229. Thomas DR, Penney CA, Majumder A, Walmsley AM (2011) Evolution of plant-made pharmaceuticals. Int J Mol Sci 12:3220-3236

230. Hefferon K (2010) Clinical trials fuel the promise of plant-derived vaccines. Am J Clin Med 7:30-37

231. Liew PS, Hair-Bejo M (2015) Farming of plant-based veterinary vaccines and their applications for disease prevention in animals. Adv Virol 2015:936940

232. MacDonald J, Doshi K, Dussault M, Hall JC, Holbrook L, Jones G, Kaldis A, Klima CL, Macdonald P, McAllister T, McLean MD, Potter A, Richman A, Shearer H, Yarosh O, Yoo HS, Topp E, Menassa R (2015) Bringing plant-based veterinary vaccines to market: managing regulatory and commercial hurdles. Biotechnol Adv 33:1572-1581

233. Phan HT, Floss DM, Conrad U (2013) Veterinary vaccines from transgenic plants: highlights of two decades of research and a promising example. Curr Pharm Des 19:5601-5611

234. Ling HY, Pelosi A, Walmsley AM (2010) Current status of plant-made vaccines for veterinary purposes. Expert Rev Vaccines 9:971-982

235. Jones RM, Chichester JA, Manceva S, Gibbs SK, Musiychuk K, Shamloul M, Norikane J, Streatfield SJ, van de Vegte-Bolmer M, Roeffen W, Sauerwein RW, Yusibov V (2015) A novel plant-produced Pfs25 fusion subunit vaccine induces long-lasting transmission blocking antibody responses. Hum Vaccin Immunother 11:124-132

236. Tiwari S, Verma PC, Singh PK, Tuli R (2009) Plants as bioreactors for the production of vaccine antigens. Biotechnol Adv 27:449-467

237. Wang L, Coppel RL (2008) Oral vaccine delivery: can it protect against non-mucosal pathogens? Expert Rev Vaccines 7:729-738

238. Zimran A, Brill-Almon E, Chertkoff R, Petakov M, Blanco-Favela F, Munoz ET, SolorioMeza SE, Amato D, Duran G, Giona F, Heitner R, Rosenbaum H, Giraldo P, Mehta A, Park G, Phillips M, Elstein D, Altarescu G, Szleifer M, Hashmueli S, Aviezer D (2011) Pivotal trial 
with plant cell-expressed recombinant glucocerebrosidase, taliglucerase alfa, a novel enzyme replacement therapy for Gaucher disease. Blood 118:5767-5773

239. Liu W, Burdick JA, van Osch GJ (2013) Plant-derived recombinant human collagen: a strategic approach for generating safe human ECM-based scaffold. Tissue Eng Part A 19:1489-1490

240. Xu J, Shpak E, Gu T, Moo-Young M, Kieliszewski M (2005) Production of recombinant plant gum with tobacco cell culture in bioreactor and gum characterization. Biotechnol Bioeng 90:578-588

241. Snell KD, Singh V, Brumbley SM (2015) Production of novel biopolymers in plants: recent technological advances and future prospects. Curr Opin Biotechnol 32:68-75 